\title{
Structural Components of Synaptic Plasticity and Memory Consolidation
}

\author{
Craig H. Bailey ${ }^{1,2,3}$, Eric R. Kandel ${ }^{1,2,3,4}$, and Kristen M. Harris ${ }^{5}$ \\ ${ }^{1}$ Department of Neuroscience, College of Physicians and Surgeons of Columbia University, \\ New York, New York 10027 \\ ${ }^{2}$ New York State Psychiatric Institute, New York, New York 10032 \\ ${ }^{3}$ Kavli Institute for Brain Sciences, New York, New York 10032 \\ ${ }^{4}$ Howard Hughes Medical Institute, Chevy Chase, Maryland 20815-6789 \\ ${ }^{5}$ Department of Neuroscience, Center for Learning and Memory, Institute for Neuroscience, \\ The University of Texas at Austin, Austin, Texas 78712-0805 \\ Correspondence: chb1@columbia.edu
}

Consolidation of implicit memory in the invertebrate Aplysia and explicit memory in the mammalian hippocampus are associated with remodeling and growth of preexisting synapses and the formation of new synapses. Here, we compare and contrast structural components of the synaptic plasticity that underlies these two distinct forms of memory. In both cases, the structural changes involve time-dependent processes. Thus, some modifications are transient and may contribute to early formative stages of long-term memory, whereas others are more stable, longer lasting, and likely to confer persistence to memory storage. In addition, we explore the possibility that trans-synaptic signaling mechanisms governing de novo synapse formation during development can be reused in the adult for the purposes of structural synaptic plasticity and memory storage. Finally, we discuss how these mechanisms set in motion structural rearrangements that prepare a synapse to strengthen the same memory and, perhaps, to allow it to take part in other memories as a basis for understanding how their anatomical representation results in the enhanced expression and storage of memories in the brain.

Santiago Ramón y Cajal (1894) used the inS sights provided by his remarkable light microscopic observations of neurons selectively stained with the Golgi method to propose the first cellular theory of memory storage as an anatomical change in the functional connections between nerve cells, later called synapses (Sherrington 1897). For most of the last century, chemical synapses were thought to convey in- formation in only one direction-from the presynaptic to the postsynaptic neuron. It now is clear that synaptic transmission is a bidirectional and self-modifiable form of cell-cell communication (Peters et al. 1976; Jessell and Kandel 1993). This appreciation of reciprocal signaling between pre- and postsynaptic elements is consistent with other forms of intercellular communication and provides a concep-

Editors: Eric R. Kandel, Yadin Dudai, and Mark R. Mayford

Additional Perspectives on Learning and Memory available at www.cshperspectives.org

Copyright (C) 2015 Cold Spring Harbor Laboratory Press; all rights reserved; doi: 10.1101/cshperspect.a021758

Cite this article as Cold Spring Harb Perspect Biol 2015;7:a021758 
C.H. Bailey et al.

tual framework for understanding memory-induced changes in the structure of the synapse. Indeed, an increasing body of evidence suggests that trans-synaptic signaling and coordinated recruitment of pre- and postsynaptic mechanisms underlie consolidation of both implicit and explicit forms of memory storage (Marrone 2005; Hawkins et al. 2006; Bailey et al. 2008).

Studies in a variety of systems have found that molecular mechanisms of consolidation and long-term storage of memory begin at the level of the synapse. Existing proteins are modified, signals are sent back to the nucleus so that specific genes are expressed, and gene products are transported back to the synapse where the local synthesis of new protein is triggered to allow for the remodeling, addition, and elimination of synapses (Bailey and Kandel 1985; Bailey et al. 1996; Kandel 2001; Bourne and Harris 2008, 2012). These structural components of synaptic plasticity are thought to represent a cellular change that contributes to both implicit and explicit memory consolidation (Greenough and Bailey 1988; Bailey and Kandel 1993; Bailey et al. 2005; Bourne and Harris 2008, 2012). The association between alterations in the structure and/or number of synapses and memory storage has led to numerous studies regarding the signaling pathways that might couple molecular changes to structural changes. In addition, parallel homeostatic mechanisms have been identified that can trigger synaptic scaling, which serves to stabilize the strengthened synapses while weakening or eliminating other synapses, thus providing specificity during memory consolidation (Bourne and Harris 2011; Schacher and $\mathrm{Hu} 2014$ ).

In this review, we compare and contrast structural changes at the synapse during both implicit and explicit memory consolidation, as well as the molecular signaling pathways that initiate the learning-induced structural changes versus those that serve to maintain these changes over time. Toward that end, we will focus on two experimental model systems and several prototypic forms of synaptic plasticity that we have worked on and that have been extensively studied as representative examples of memory storage: long-term habituation and sensitization of the gill-withdrawal reflex in Aplysia. These are examples of implicit memory consolidation and hippocampal-based long-term potentiation (LTP) and long-term depression (LTD), as candidate mechanisms for the synaptic plasticity underlying explicit memory storage in mammals. These will serve as useful points of comparison to consider similarities, differences, and still-existing limitations in our understanding of the functional significance of the structural synaptic plasticity recruited during the consolidation of both implicit and explicit forms of memory.

\section{STRUCTURAL CHANGES AND CONSOLIDATION OF IMPLICIT BEHAVIORAL MEMORY}

Structural mechanisms contributing to implicit memory storage have been most extensively studied for sensitization of the gill-withdrawal reflex in Aplysia (Kandel 2009). Sensitization is an elementary form of nonassociative learning, a form of learned fear, by which an animal learns about the properties of a single noxious stimulus. When a light touch is applied to the siphon of an Aplysia, it responds by withdrawing its gill and siphon. This response is enhanced when the animal is given a noxious, sensitizing stimulus, such as a mild shock to its tail. The memory for sensitization of the withdrawal reflex is graded: a single tail shock produces short-term sensitization that lasts for minutes, whereas five repeated tail shocks given at spaced intervals produce long-term sensitization that lasts for up to several weeks (Frost et al. 1985). Both short- and longterm sensitization lead to enhanced transmission at a critical synaptic locus: the monosynaptic connection between identified mechanoreceptor sensory neurons and their follower cells.

In the early 1980s, studies in Aplysia began to explore the structural changes that underlie memory consolidation: the transition from short- to long-term sensitization. By combining selective intracellular-labeling techniques with the analysis of serial thin sections and transmission electron microscopy (TEM), complete 3D reconstructions of unequivocally identified sensory neuron synapses were quantitatively ana- 
lyzed from both control and behaviorally modified animals (Fig. 1).

The storage of long-term memory for sensitization (lasting several weeks) was accompanied by two classes of structural changes at identified synapses between the sensory neurons and their target neurons: (1) a remodeling of the preexisting presynaptic compartment leading to an increase in the number, size, and vesicle complement of the active zones (regions modified for transmitter release) of sensory neurons from sensitized animals compared
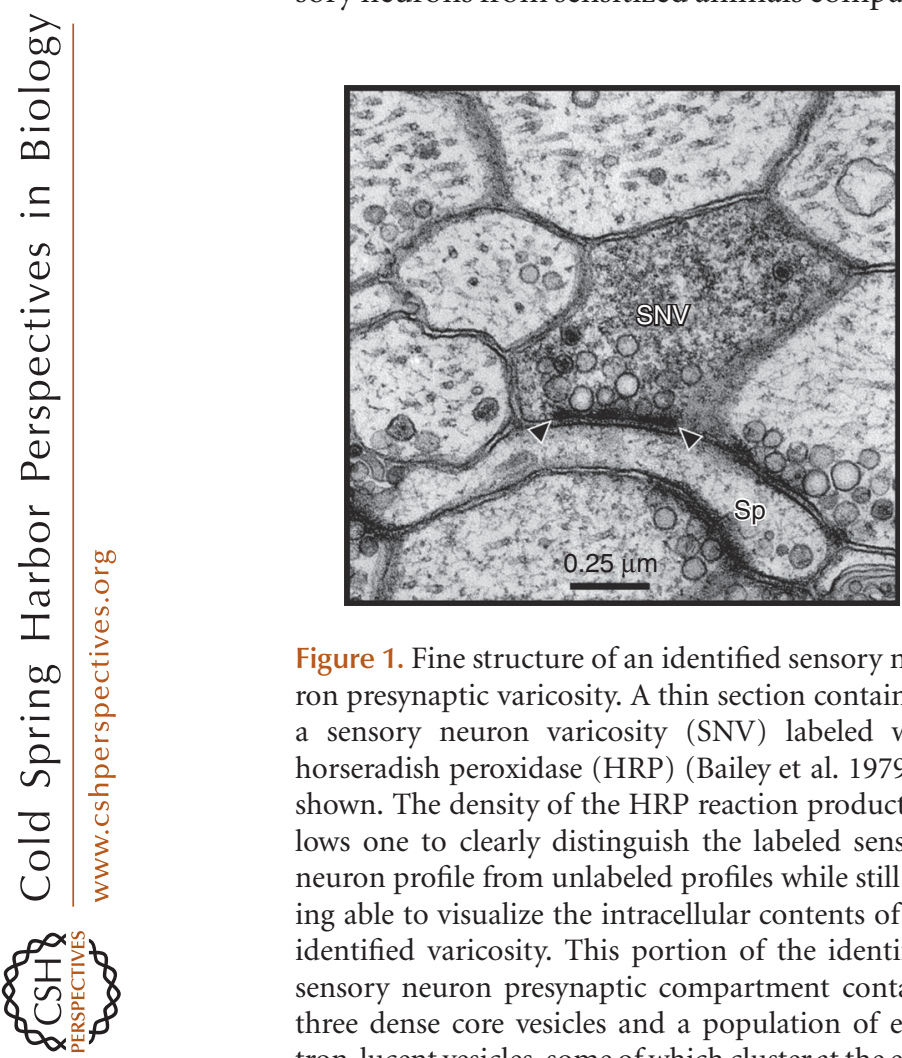

Figure 1. Fine structure of an identified sensory neuron presynaptic varicosity. A thin section containing a sensory neuron varicosity (SNV) labeled with horseradish peroxidase (HRP) (Bailey et al. 1979) is shown. The density of the HRP reaction product allows one to clearly distinguish the labeled sensory neuron profile from unlabeled profiles while still being able to visualize the intracellular contents of the identified varicosity. This portion of the identified sensory neuron presynaptic compartment contains three dense core vesicles and a population of electron-lucent vesicles, some of which cluster at the electron-dense specializations that define the active zone (between arrow heads). In this thin section, the labeled sensory neuron presynaptic varicosity forms a synaptic contact with an unlabeled postsynaptic dendritic spine ( $\mathrm{Sp}$ ) of a follower neuron. By combining this selective intracellular-labeling technique with the analysis of serial thin sections and transmission EM, complete 3D reconstructions of active zone morphology (number, size, and vesicle complement) in unequivocally identified sensory neuron synapses were quantitatively analyzed from both control and behaviorally modified animals. (Unpublished electron micrograph courtesy of Mary Chen and Craig Bailey.) with untrained controls (Bailey and Chen 1983, 1988b), and (2) a more expansive growth process that led to a twofold increase in the number of synaptic varicosities (boutons), as well as an enlargement of each neuron's synaptic arbor when compared with sensory neurons from untrained animals (Fig. 2) (Bailey and Chen 1988a). Moreover, in control animals, $\sim 60 \%$ of the fully reconstructed varicosities lacked a structurally detectable active zone (Bailey and Chen 1983). The extent to which learning can convert these nascent and presynaptically silent synapses into mature and functionally competent synaptic connections is discussed below.

By comparing the time course for each class of morphological change with the behavioral duration of the memory, Bailey and Chen (1989) found that only the increases in the number of varicosities and active zones, which persisted unchanged for at least 1 week and were partially reversed at the end of 3 weeks, paralleled the time course of behavioral memory storage and, thus, could contribute to the retention of long-term sensitization. These results directly correlate a change in the structure of an identified synapse to a long-lasting behavioral memory and suggest that the morphological alterations could represent an anatomical substrate for memory consolidation. The learning-induced growth of new sensory neuron synapses in the abdominal ganglion that accompanies long-term sensitization of the gill-withdrawal reflex also was found to occur in subsequent behavioral studies of sensitization in the pleural ganglion mediating the tail-siphon withdrawal reflex in Aplysia (Wainwright et al. 2002).

In addition to long-term sensitization, Bailey and Chen (1983, 1988a) also examined, in the same studies, the structural correlates of long-term habituation. Unlike what they observed following long-term sensitization, this behavioral form of persistent synaptic depression was associated with decreases in the number, size, and vesicle complement of sensory neuron active zones, as well as a $35 \%$ reduction in the total number of synapses that the sensory neurons make on their follower cells when compared with sensory neurons from untrained animals. Thus, long-term behavioral modifica- 
C.H. Bailey et al.
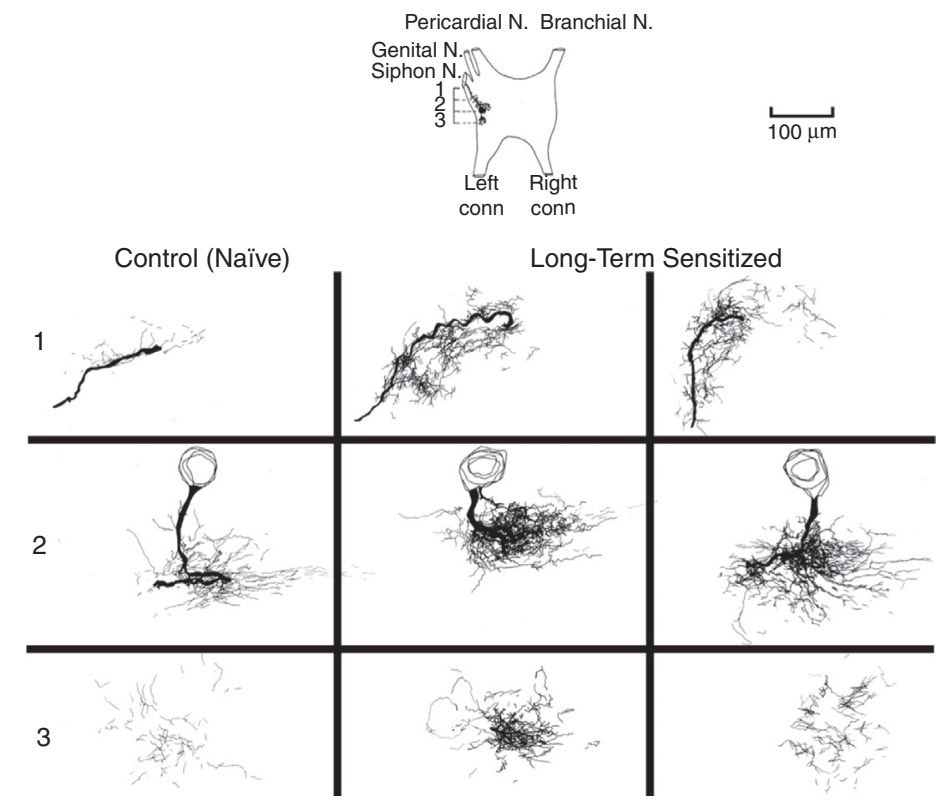

Figure 2. Learning-related growth of the sensory neuron synaptic arbor induced by long-term sensitization in Aplysia. Serial 3D reconstructions of identified sensory neurons labeled with horseradish peroxidase (HRP) from long-term sensitized and control animals are shown. Total extent of the synaptic neuropil arbors of sensory neurons from one control (untrained) and two long-term sensitized animals are shown. In each case, the rostral (row 3) to caudal (row 1) extent of the arbor is divided roughly into thirds. Each panel was produced by the superimposition of camera lucida tracings of all HRP-labeled processes present in 17 consecutive slab-thick Epon sections and represents a linear segment through the ganglion of roughly $340 \mu \mathrm{m}$. For each composite, ventral is up, dorsal is down, lateral is to the left, and medial is to the right. By examining images across each row (rows 1,2, and 3), the viewer is comparing similar regions of each sensory neuron. In all cases, the synaptic arbor of long-term sensitized cells is markedly expanded compared with cells from control (untrained) animals, and parallels the concomitant twofold increase in the total number of sensory neuron presynaptic varicosities. (From Bailey and Chen 1988a; modified, with permission.)

tions in Aplysia not only can induce the growth of new synaptic connections, but also the pruning of preexisting connections.

This bidirectional structural remodeling of the same synapse following opposing forms of learning, in turn, provided some insights into how the anatomical representations of enduring memories might be accomplished at the more complex systems level. In the mammalian brain, each memory is likely to be distributed and embedded in many synaptic connections. Clearly, the brain cannot accommodate the storage of such a large number of memories by constant growth of new synaptic connections alone. The studies on long-term habituation in Aplysia provide an experimental foundation for an alternative hypothesis, that is, although initial long- term storage may be dependent on a growth process, the brain appears to have the ability to reorganize and refine this representation in an experience-dependent fashion by pruning old or inappropriate synapses, thus reducing the total number of synapses required to carry each memory over time. A corollary of this would be the prediction that as a memory is strengthened over time, which is thought to occur with retrieval and recall, no new synapses would form, but rather there is an increase of signal-to-noise as the appropriate synapses are enlarged and strengthened, whereas the inappropriate synapses are eliminated (see, for example, Xu et al. 2009; Yang et al. 2009; Bourne and Harris 2011).

These initial studies in Aplysia showed that learning-induced structural changes occur at the 
level of specific identified synapses known to be critically involved in the behavioral modification providing direct evidence supporting $\mathrm{Ra}$ món y Cajal's prescient suggestions that synaptic connections between neurons are not immutable, but are modified by learning and may serve as key components of memory expression and storage. Moreover, the growth of new synapses may represent a stable component required for the consolidation of memory storage and raises the possibility that the persistence of the longterm process might be achieved, at least in part, because of the relative stability of these changes in synaptic structure (Bailey and Chen 1990; Bailey 1991; Bailey and Kandel 2008a).

\section{IMPLICIT MEMORY MECHANISMS CAN BE RECONSTITUTED IN CULTURED APLYSIA NEURONS}

The simplicity of the neuronal circuit underlying sensitization, including direct monosynaptic connections between identified mechanoreceptor sensory neurons and their follower cells (Castellucci et al. 1970), has allowed reduction of the analysis of the short- and long-term memory for sensitization to the cell and molecular level. This monosynaptic sensory to motor neuron connection, which is glutamatergic, can be reconstituted in dissociated cell culture and reproduces what is observed during behavioral training by replacing tail shocks with brief applications of serotonin (5-HT), a modulatory transmitter normally released by sensitizing stimuli in the intact animal (Montarolo et al. 1986; Marinesco and Carew 2002). A single, brief application of 5-HT produces a shortterm change in synaptic effectiveness (shortterm facilitation $[\mathrm{STF}]$ ), whereas repeated and spaced applications produce changes in synaptic strength that can last for more than a week (long-term facilitation [LTF]).

The molecular changes associated with STF and LTF differ fundamentally in at least two ways. First, the long-term but not the shortterm changes require the activation of transcription and new protein synthesis (Schwartz et al. 1971; Montarolo et al. 1986; Castellucci et al. 1989). Second, as we have just seen at the behavioral level, the long-term but not the short-term processes involve the growth of new sensory-to-motor-neuron synapses, which, when reconstituted in dissociated cell culture, are induced by five repeated applications of 5HTand depend on transcription and translation (Bailey et al. 1992b) as well as the presence of an appropriate target cell similar to the synapse formation that occurs during development (Glanzman et al. 1990).

\section{REMODELING AND ACTIVATION OF PREEXISTING SILENT SYNAPSES DURING LTF}

Kim et al. (2003) followed remodeling and growth at the same specific synaptic varicosities continuously over time and examined the functional contribution of these presynaptic structural changes to different time-dependent phases of facilitation. Live time-lapse confocal imaging was performed on sensory neurons containing the whole cell marker Alexa-594, and the presynaptic marker proteins synaptophysin-eGFP and synapto-PHluorin (synPH), which monitor changes in synaptic vesicle distributions and active transmitter-release sites, respectively. The results showed that initially, when a sensory neuron was cocultured with its postsynaptic motor neuron L7, 12\% of the presynaptic varicosities that were labeled with Alexa-594 lacked synaptophysin-eGFP and synPH labeling and, thus, were not competent to release transmitter. Repeated pulses of 5-HT induced a rapid activation of these silent presynaptic terminals through the filling of preexisting empty (nascent) varicosities with synaptic vesicles and active zone material. This filling and unsilencing of preexisting sensory neuron varicosities began at $0.5 \mathrm{~h}$ after exposure to the five pulses of 5-HT, was completed within $3-6 \mathrm{~h}$, and accounted for $\sim 32 \%$ of the newly activated synapses present at $24 \mathrm{~h}$. Thus, the rapid activation of silent presynaptic varicosities suggests that, in addition to its role in LTF, this remodeling of preexisting nascent synapses may also contribute to the intermediate phases of synaptic plasticity and implicit memory storage (Fig. 3) (Ghirardi et al. 1995; Mauelshagen et al. 1996; Sutton et al. 2001). 
C.H. Bailey et al.

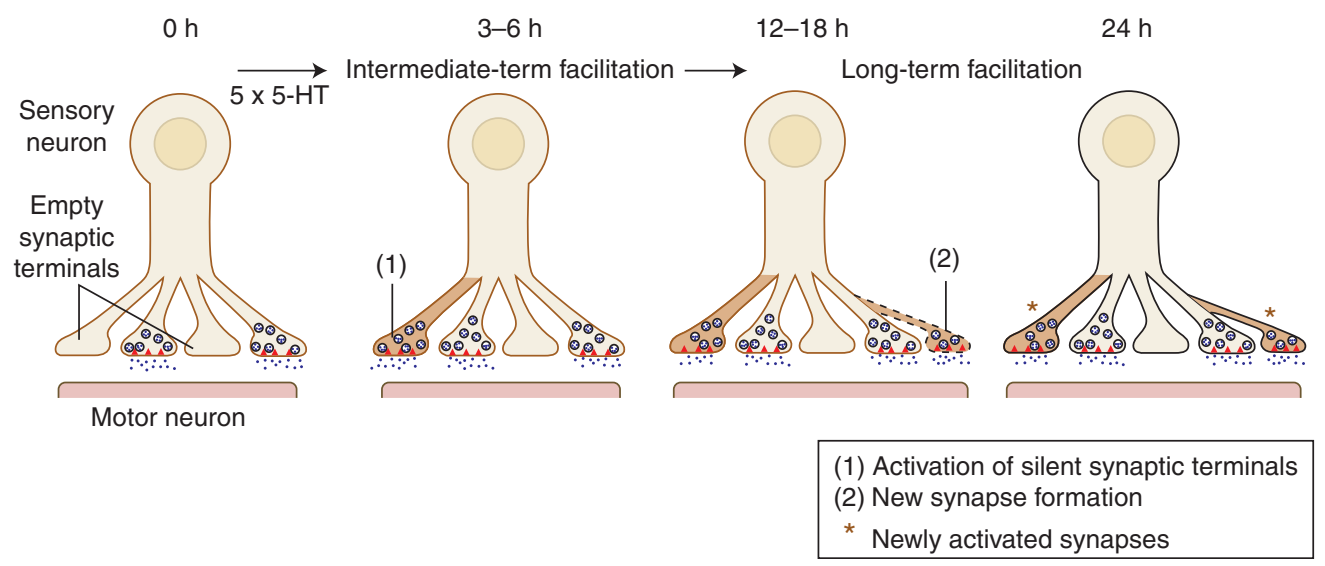

Figure 3. Time course and functional contribution of two distinct presynaptic structural changes associated with intermediate-term facilitation and long-term facilitation (LTF) in Aplysia. Repeated pulses of 5-HT in sensory to motor neuron cocultures trigger two distinct classes of learning-related presynaptic structural changes: (1) the rapid filling of synaptic vesicles and active zone material to preexisting silent sensory neuron varicosities (3$6 \mathrm{~h}$ ), and (2) the slower generation of new sensory neuron synaptic varicosities ( $12-18 \mathrm{~h}$ ). The resultant newly filled and newly formed varicosities are functionally competent (capable of evoked transmitter release) and contribute to the synaptic enhancement that underlies LTF measured at $24 \mathrm{~h}$. The rapid filling and activation of silent presynaptic terminals at $3 \mathrm{~h}$ suggests that, in addition to its role in LTF, this remodeling of preexisting varicosities may also contribute to the intermediate phase of synaptic plasticity. Red triangles represent transmitter-release sites (active zones). (From Kim et al. 2003; modified, with permission.)

\section{LEARNING-RELATED ADDITION OF NEW FUNCTIONAL SYNAPSES DURING LTF}

LTF also is accompanied by a second class of learning-related presynaptic structural change: a slower generation of new and functionally effective sensory neuron varicosities. Time-lapse imaging revealed that new sensory neuron varicosities began to form $12-18 \mathrm{~h}$ after exposure to five pulses of 5-HT and accounted for $68 \%$ of newly activated synapses at $24 \mathrm{~h}$ (Kim et al. 2003).

How are these new varicosities formed? The 5-HT-induced recruitment of synaptic vesicles and active zone material to a preexisting varicosity leads directly to both an enrichment of these presynaptic constituents, as well as to an overall increase in the size of the varicosity. The presynaptic remodeling and growth is followed by the apparent division or splitting of a subset of these preexisting varicosities (Hatada et al. 2000; Kim et al. 2003; Udo et al. 2005). This dynamic process may lead to the budding off of components of the active zone and cognate synaptic vesicle cluster from each preexisting presynaptic compartment, similar to the creation of "orphan-release sites" in mammalian cultures (Ziv and Garner 2004), which could then serve as nucleation loci to seed the subsequent differentiation and establishment of new presynaptic varicosities (Bailey and Kandel 2008b).

These findings, the first to be made on individually identified presynaptic varicosities, suggest that the duration of changes in synaptic effectiveness that accompany different phases of memory storage may be reflected by the differential regulation of two fundamentally disparate forms of presynaptic compartment: (1) nascent, silent varicosities that can be rapidly and reversibly remodeled into active transmitter-release sites, and (2) mature, more stable, and functionally competent varicosities that, following long-term training, may undergo a process of fission to form new stable synaptic contacts.

These morphological findings, in turn, raised the question: What are the cellular and molecular mechanisms responsible for in these two distinct classes of learning-related presynaptic structural change? 


\section{INITIAL STEPS OF LEARNING-RELATED SYNAPTIC GROWTH IN APLYSIA}

Spontaneous Transmitter Release and Trans-synaptic Recruitment of Pre- and Postsynaptic Mechanisms

Similar to synaptogenesis during development (McAllister 2007), the growth of new synaptic connections induced by learning in the adult requires the participation of both pre- and postsynaptic components of the synapse. In Aplysia, a newly discovered intermediate phase of memory initiates structural remodeling in preexisting synapses, which, in turn, serves as an early step contributing to the synaptic growth during the long-term phase and, therefore, requires participation of both pre- and postsynaptic components of the synapse, although not transcription (Ghirardi et al. 1995; Kim et al. 2003). Jin et al. (2012a,b) found that application of protein kinase A (PKA), which initiates the intermediate phase, leads to an increase in spontaneous transmitter release from the presynaptic sensory neuron and provides the critical trans-synaptic signal for recruitment of the molecular machinery of the postsynaptic motor neuron and subsequent remodeling of preexisting synapses, which represent the initial steps of synaptic growth. The spontaneous release is regulated by an Aplysia neurotrophin (ApNT) ligand (Kassabov et al. 2013) released by the presynaptic neuron that contributes, in a PKA-dependent manner, to intermediate-term facilitation by enhancing spontaneous transmitter release (Hawkins et al. 2012) and inducing growth. ApNT does so, in part, by contributing an autocrine signal to the presynaptic sensory neurons via its cognate Trk autoreceptors. Spontaneous release activates postsynaptic metabotropic glutamate receptors (mGluR5), which increase IP3 production, causing release of calcium from intracellular stores, which leads to the insertion of new $\alpha$-amino-3-hydroxy-5-methyl-4-isoxazolepropionic acid (AMPA) receptors (Jin et al. 2012a,b) and the first phase of remodeling in the postsynaptic neuron. Blocking the postsynaptic $\mathrm{Ca}^{2+}$ signal blocks postsynaptic participation and growth.

\section{Remodeling of the Presynaptic Actin Network}

The 5-HT-induced enrichment of synaptic vesicle proteins and recruitment of active zone components in both preexisting and newly formed sensory neuron synapses during LTF in cultured Aplysia neurons involve an activity-dependent rearrangement of the presynaptic actin cytoskeleton (Udo et al. 2005; see also Hatada et al. 2000). Application of toxin B, a general inhibitor of the Rho family of proteins, blocks 5-HT-induced LTF, as well as growth of new synapses in sensorimotor neuron coculture. Moreover, repeated pulses of 5-HT selectively induce the spatial and temporal regulation of the activity of one of the small Rho families of GTPases, Cdc42, at a subset of sensory neuron presynaptic varicosities. The activation of ApCdc42 induced by 5 -HT is dependent on both the phosphoinositide-3-kinase (PI3K) and phospholipase $\mathrm{C}$ (PLC) pathways and, in turn, recruits the downstream effectors p21-activated kinase (PAK) and neuronal Wiskott-Aldrich syndrome protein (N-WASP) to regulate and remodel the presynaptic actin network.

\section{Three Types of Cell-Adhesion Molecule- Mediated Trans-synaptic Interactions}

De novo synapse formation during development requires specific trans-synaptic protein interactions. This is also true for learning-induced synaptic growth in Aplysia. These trans-synaptic interactions, which reflect a second, later stage in synaptic growth-the generation of new functionally competent varicosities (Kim et al. 2003)_involve at least three types of celladhesion interactions. The selective 5-HT-induced, clathrin-mediated internalization of the transmembrane isoform of an immunoglobulin-related cell-adhesion molecule in Aplysia (apCAM) in the presynaptic sensory neuron is thought to be a preliminary and permissive step for the expression of LTF and synaptic growth (Fig. 4) (Bailey et al. 1992a, 1997; Mayford et al. 1992; Han et al. 2004). Down syndrome cell-adhesion molecule (Dscam) is required both pre- and postsynaptically for clustering of AMPA receptors and the emergence of new synaptic connections ( $\mathrm{Li}$ et al. 2009). In addition, 


\section{C.H. Bailey et al.}
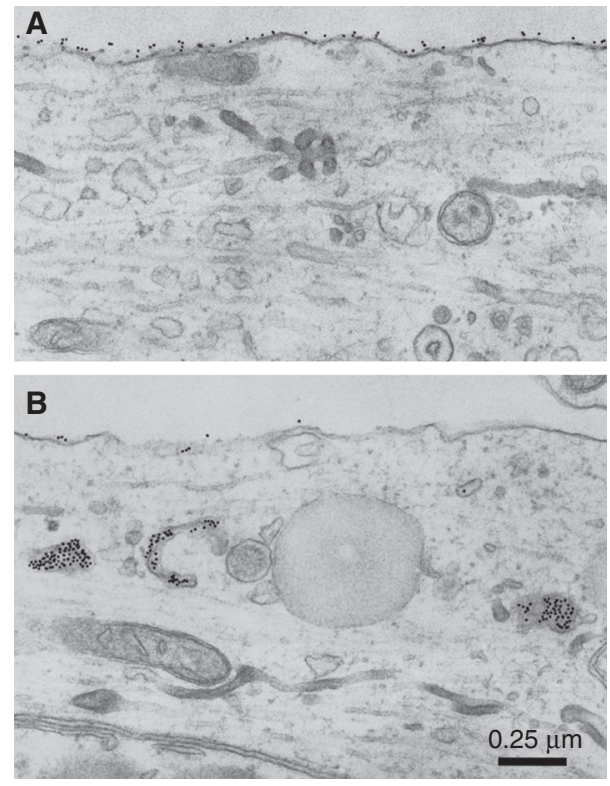

Figure 4. Differential down-regulation of the glycosyl-phosphoinositol (GPI)-linked versus transmembrane isoforms of cell-adhesion molecule in Aplysia (apCAM): the role in learning-related synaptic growth. Some of the first evidence for a role of celladhesion molecules (CAMs) during learning and memory came from studies of an immunoglobulinrelated CAM in Aplysia, designated apCAM, which is homologous to neural cell-adhesion molecules (NCAMs) in vertebrates and Fasciclin II in Drosophila. To determine the fate of the two isoforms of apCAM in learning-related synaptic growth, gold-conjugated epitope-tagged constructs of either the transmembrane (TM) or GPI-linked isoforms were overexpressed in Aplysia sensory neurons. (A) Neurite of a sensory neuron expressing the GPI-linked isoform of apCAM following a 1-h exposure to 5-HT. Note, virtually all of the gold complexes (black dots) remain on the surface membrane with none inside despite a robust 5-HT-induced activation of the endosomal pathway leading to significant accumulations of internal membranous profiles. (B) Neurite of a sensory neuron expressing the transmembrane isoform of apCAM following a 1-h exposure to 5-HT. In contrast to the lack of down-regulation of the GPI-linked isoform, 5-HT has a dramatic effect on the transmembrane isoform of apCAM, removing most of it from the surface membrane, resulting in heavy accumulations of gold complexes within presumptive endocytic compartments. This 5-HT-induced, clathrinmediated selective internalization of the transmembrane isoform of apCAM in the presynaptic sensory neuron leads to: (1) defasciculation, a process that neurexin (presynaptic) and neuroligin (postsynaptic) are required for both LTF and the associated synaptic growth induced by serotonin. Interestingly, introduction into the motor neuron of the R451C mutation of neuroligin-3, which is linked to autism, interrupts transsynaptic signaling and blocks both intermediateterm facilitation and LTF (Choi et al. 2011).

\section{Signaling from the Synapse to the Nucleus}

Studies in Aplysia-cultured neurons also have explored how signals from the synapse are sent to the nucleus and how activity at the synapse informs the nucleus to alter transcription. Earlier work had shown that repeated pulses of 5-HT activate PKA, which recruits mitogenassociated protein kinase (MAPK), and both translocate to the nucleus where they phosphorylate transcription factors and activate gene expression required for the induction of longterm memory (Bacskai et al. 1993; Martin et al. 1997b). In more recent studies, Lee et al. (2007, 2012) found that the repeated pulses of serotonin required to induce LTF and activate PKA, in turn, phosphorylate CAM-associated protein (CAMAP), a transcriptional regulator that is tethered to the synapse via the cell-adhesion molecule (CAM), apCAM. Phosphorylation of CAMAP dissociates it from apCAM, leading to the internalization of apCAM described above and also the translocation of CAMAP from the synapse to the nucleus of sensory neurons, where it contributes to activating CREB1 and

destabilizes adhesive contacts normally inhibiting synaptic growth, (2) endocytic activation that results in a redistribution of membrane components to sites in which new synapses form, and, finally, (3) the normal expression of long-term facilitation (LTF) and synaptic growth. These findings also suggest that previously established connections might remain intact following exposure to 5 -HT because they would be held in place by the adhesive, homophilic interactions of the GPI-linked isoforms, and the process of outgrowth from sensory neuron axons would be initiated by down-regulation of the transmembrane form at extrasynaptic sites of membrane apposition. (From Bailey et al. 1997; modified, with permission.) 
ApC/EBP-mediated transcription (Alberini et al. 1994) required for the initiation of synaptic growth and LTF. This retrograde signaling also removes the inhibition of microRNA 124, thereby enhancing the activation of CREB-1 and leading to activation of piRNA-F, which methylates and shuts off the promoter of CREB-2, the repressor gene, for $>24 \mathrm{~h}$, allowing the action of CREB to be prolonged (Rajasethupathy et al. 2009, 2012).

\section{Coordinated Transport from the Cell Body to the Synapse}

Puthanveettil et al. (2008) considered how anterograde signaling and the gene products, required for the initiation of synaptic growth, move from the cell body of the sensory neuron to its presynaptic terminals, and from the cell body of the motor neuron to its postsynaptic dendritic spines. The induction of LTF and synaptic growth requires up-regulation of the molecular motor kinesin heavy chain (KHC), which mediates fast axonal transport of organelles, messenger RNAs (mRNAs), and proteins in a microtubule- and ATP-dependent manner. Kinesins are rapidly up-regulated in both preand postsynaptic neurons by five pulses of 5-HT. Moreover, inhibition of ApKHC1 in either the pre- or postsynaptic neuron blocks induction of LTF, whereas up-regulation of KHC in the presynaptic neurons alone is sufficient for the induction of LTF. The mRNA and protein cargo associated with ApKHC includes neurexin and neuroligin involved in de novo synapse formation and piccolo and bassoon proteins required for formation and stabilization of the presynaptic active zone. These data support the idea that the building blocks important for the final stages of new synapse formation induced by learning need to be transported in a coordinated fashion from the cell body to the synapses.

\section{STABILIZATION OF NEW SYNAPSES DURING LTF IN APLYSIA}

Studies of synapse-specific long-term plasticity in Aplysia first suggested the molecular mecha- nisms underlying the initiation of LTF and synaptic growth are likely to differ from those required for their long-term maintenance (Martin et al. 1997a; Casadio et al. 1999; Si et al. 2003). Induction of changes in synaptic function and structure, measured $24 \mathrm{~h}$ after 5-HT treatment, requires only nuclear transcription and somatic translation, whereas persistence of these synaptic modifications, measured at $72 \mathrm{~h}$, requires, in addition, local protein synthesis at the synapse (Casadio et al. 1999).

To determine the role of local protein synthesis and its time window in stabilization of learning-related synaptic growth and persistence of LTF, Miniaci et al. (2008) used the modified Aplysia culture system, consisting of a single bifurcated sensory neuron contacting two spatially separated motor neurons (Martin et al. 1997a). Local application of emetine, an inhibitor of protein synthesis, to one set of sensorimotor neuron synapses following five pulses of 5-HT blocked LTF when given at either $24 \mathrm{~h}$ or $48 \mathrm{~h}$, but had no effect when applied at $72 \mathrm{~h}$ after 5-HT. The inhibition of local protein synthesis at $24 \mathrm{~h}$ led to a selective retraction of newly formed varicosities induced by $5-\mathrm{HT}$ when compared with preexisting varicosities (Fig. 5). This late phase of local protein synthesis is importantly regulated by the Aplysia homolog of cytoplasmic polyadenylation element-binding protein (ApCPEB), which promotes translational activation ( $\mathrm{Si}$ et al. 2003). Local application of a specific TAT-antisense (TAT-AS) oligonucleotide to ApCPEB $24 \mathrm{~h}$ after repeated pulses of 5-HT blocked the stable maintenance of both LTF and synaptic growth (Fig. 6).

Combined, these results defined a temporally distinct and local phase of stabilization, indicating that the consolidation process for learning-related synaptic growth extends to $\sim 72 \mathrm{~h}$. During this time, 5-HT-induced newly formed varicosities are labile and require sustained CPEB-dependent local protein synthesis to acquire the more stable properties of mature varicosities (for additional self-sustaining, molecular modifications that may lead to the longterm maintenance of structural changes and memory storage, see also Bailey et al. 2004 and Si 2015). 
C.H. Bailey et al.

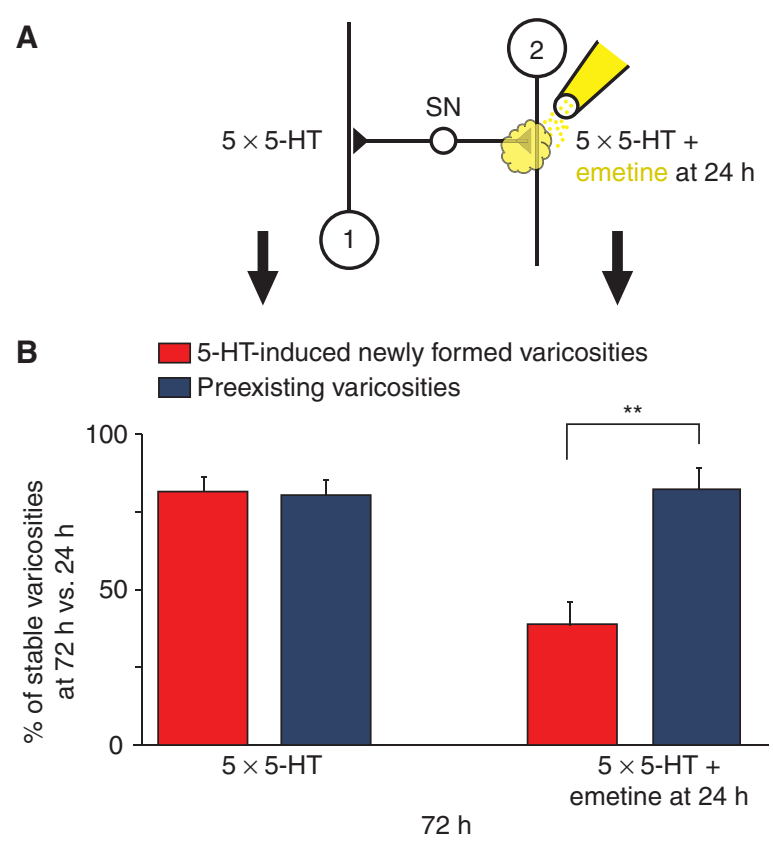

Figure 5. Local perfusion of emetine at $24 \mathrm{~h}$ leads to a selective retraction of 5-HT-induced newly formed sensory neuron varicosities. (A) Diagram of a single bifurcated sensory neuron (SN) in contact with two spatially separated L7 gill-motor neurons (1 and 2) and experimental protocol. (B) To assess the dynamic properties of the 5-HT-induced newly formed varicosities, their stability was compared under two different experimental conditions: 5-HT (left) and 5-HT + emetine (right). Culture dishes containing the bifurcated sensory neuronmotor neuron preparation were treated with five pulses of 5-HTat time 0 and $24 \mathrm{~h}$ later, one of the two branches was perfused locally with emetine. Each individual fluorescently labeled 5-HT-induced newly formed and preexisting varicosity was imaged at $24 \mathrm{~h}$ and then the exact target field was reimaged to determine the presence or absence of the same individual varicosities at $72 \mathrm{~h}$. The number of 5-HT-induced newly formed and preexisting varicosities that were present at $72 \mathrm{~h}$ were compared with the number of varicosities in the same respective class observed at $24 \mathrm{~h}$. At the branch that only received 5-HT, 81.3\% of the 5-HT-induced newly formed varicosities (red, left) and $80.3 \%$ of the preexisting varicosities (blue, left) were maintained at $72 \mathrm{~h}$ when compared with $24 \mathrm{~h}$. In contrast, at the branch that received emetine $24 \mathrm{~h}$ after 5 -HT treatment, only $38.1 \%$ of the 5-HT-induced newly formed varicosities (red, right) were maintained at $72 \mathrm{~h}$ versus $81.63 \%$ of the preexisting varicosities (blue, right). In both cases, the 5-HT-induced new varicosities represent varicosities that formed between 0 and $24 \mathrm{~h}$ and remained stable at $72 \mathrm{~h}$. Each histogram illustrates the mean percentage ( \pm SEM) of identified varicosities maintained at $72 \mathrm{~h}$ compared with $24 \mathrm{~h}$. The selective retraction of 5-HTinduced newly formed varicosities induced by local application of emetine shows that during the stabilization phase this population of learning-related varicosities is significantly more labile and sensitive to disruption than the population of preexisting sensory neuron varicosities. (From Miniaci et al. 2008; modified, with permission.)

\section{LTP AS A MODEL SYNAPTIC MECHANISM CONTRIBUTING TO CONSOLIDATION OF EXPLICIT MEMORY STORAGE IN THE MAMMALIAN BRAIN}

As is the case with implicit memory storage in invertebrates, explicit, hippocampal-based memory is also stored by means of structural changes at the synapse. Much of the work on synaptic plasticity as a cellular mechanism of hippocampal learning and memory has been performed using the model systems of LTP and LTD (Bliss et al. 2013). LTP is a persistent increase in synaptic strength induced by brief high-frequency stimulation, whereas LTD is a persistent decrease in synaptic strength induced 

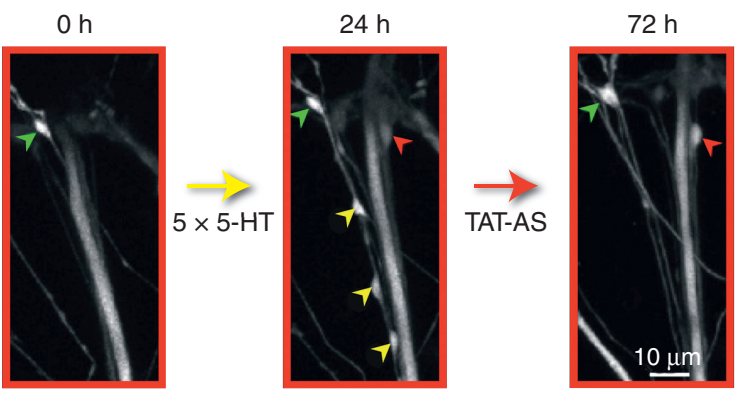

Figure 6. A late phase of sustained cytoplasmic polyadenylation element-binding (CPEB) protein-dependent local protein synthesis is required to stabilize learning-related synaptic growth. A specific Aplysia CPEB (ApCPEB) antisense oligonucleotide covalently coupled to an 11-amino-acid peptide derived from the HIVTAT protein (TAT-antisense [TAT-AS]) was locally perfused to one branch of the bifurcated sensorimotor neuron culture preparation for $30 \mathrm{~min}$ at $24 \mathrm{~h}$ after 5-HT treatment. This antisense oligo has previously been shown to lead to the depletion of ApCPEB messenger RNA (mRNA) and to a selective decrease in the level of CPEB protein (Si et al. 2003). Local perfusion of the TAT-AS selectively reduced the number of 5-HT-induced newly formed varicosities maintained at $72 \mathrm{~h}$ compared with preexisting varicosities, similar to what was observed with the local perfusion of emetine (see Fig. 5). This figure contains confocal images of green fluorescent protein (GFP)-labeled sensory neuron presynaptic varicosities in contact with the postsynaptic motor neuron L7 (not labeled), and illustrates the results of three imaging sessions of a representative example of the entire sensory neuron-motor neuron synaptic field. Before the application of 5-HT, a single preexisting sensory neuron varicosity is present (green arrowhead) in this field of view. After repeated applications of 5-HT for $24 \mathrm{~h}$, four newly formed sensory neuron varicosities (one red and three yellow arrowheads) are present along with the single preexisting varicosity seen at time 0 . The local perfusion of TAT-AS at $24 \mathrm{~h}$ to this synaptic area induces the selective pruning of three newly formed varicosities (yellow arrowheads) without affecting the preexisting varicosity (green arrowhead). The red arrowhead represents the only 5-HT-induced newly formed varicosity in this field that is maintained at $72 \mathrm{~h}$. (From Miniaci et al. 2008; modified, with permission.)

by longer episodes of low-frequency stimulation. Two paradigms, tetanic stimulation and $\theta$-burst stimulation (TBS), have been commonly used to investigate how long LTP can last. Tetanic stimulation, involving three or more episodes of 100 pulses $(100 \mathrm{~Hz})$ delivered at 10 -min intervals, saturates LTP and last for many hours in mature hippocampal slices in vitro (Huang and Kandel 1994; Frey et al. 1995). TBS provides a more natural paradigm, resembling firing patterns of hippocampal pyramidal cells in vivo (Buzsaki et al. 1987; Staubli and Lynch 1987; Abraham and Huggett 1997; Nguyen and Kandel 1997; Morgan and Teyler 2001; Buzsaki 2002; Leinekugel et al. 2002; Hyman et al. 2003; Raymond and Redman 2006; Mohns and Blumberg 2008). TBS, producing maximal LTP, consists of eight trains delivered at 30-s intervals with each train being 10 bursts at $5 \mathrm{~Hz}$ of four pulses at $100 \mathrm{~Hz}$ (Abraham and Huggett 1997). Tetanic stimulation induces LTP primarily through the activation of $\mathrm{N}$-methyl-D-aspartate receptors (NMDARs), whereas TBS engages multiple induction mechanisms, including activation of NMDARs and voltage-gated calcium channels, back-propagating action potentials, release of calcium from intracellular stores, as well as release of brain-derived neurotrophic factor (BDNF) (Buzsaki et al. 1987; Staubli and Lynch 1987; Abraham and Huggett 1997; Nguyen and Kandel 1997; Morgan and Teyler 2001; Buzsaki 2002; Hyman et al. 2003; Raymond and Redman 2006). Like tetanic stimulation, TBS also produces LTP that lasts for $>3 \mathrm{~h}$ and has a late phase that is protein synthesis dependent (Nguyen and Kandel 1997; Kelleher et al. 2004; Martin 2004; Yang et al. 2008).

Evidence that LTP and learning share mechanisms comes from work showing that they occlude one another, namely, that a strong learning experience before testing for LTP results in less LTP and, conversely, inducing LTP in vivo 
C.H. Bailey et al.

can occlude subsequent learning (Barnes et al. 1994; Moser et al. 1998; Habib et al. 2013; Takeuchi et al. 2014). LTP and LTD interact along a sliding scale in which the more saturated with potentiation that a set of synapses becomes, the more resistant they are to additional potentiation (Abraham and Bear 1996; Abraham et al. 2001). On the contrary, the more depressed a population of synapses becomes, the more likely that subsequent stimulation will reverse the depression. The properties of LTP have been shown to depend not only on the induction protocols, but also on the time of day, and the age, strain, and species of the animal (Harris and Teyler 1983; Diana et al. 1994; ManahanVaughan and Schwegler 2011; Bowden et al. 2012; Cao and Harris 2012).

Hence, differences in structural outcomes might arise when induction is by glutamate uncaging at individual spines versus chemical, tetanic, or TBS of multiple synapses. Similarly, results may differ between young (prepubescent or cultured) versus more mature hippocampal neurons. Because more is known about the structural correlates of LTP, we focus here on the structural components of synaptic plasticity associated with LTP and recognize that although some commonalities are beginning to emerge, additional research will be needed to determine whether a uniform theory of structural plasticity underlying LTP and explicit memory can be applied across paradigms.

\section{DENDRITIC SPINES IN THE MAMMALIAN BRAIN}

The major focus of the structural plasticity studies in the hippocampus has been the dendritic spines: the postsynaptic receptive surface area of the synapse. Dendritic spines are protrusions with diverse lengths and shapes that stud the surface of many neurons throughout the brain and are the major sites of excitatory synapses. This diversity allows spines to increase the total postsynaptic surface area and, thus, more synaptic connections can form in a compact volume of neuropil than if the same synapses had to line up along a more uniform dendritic shaft (Harris and Kater 1994). Hippocampal den- dritic spines can vary up to 100 -fold in their dimensions and most of their volume is concentrated in a bulbous head, which is connected to the dendritic shaft through a constricted neck of low volume (Fig. 7) (Harris et al. 1992). A thickened postsynaptic density (PSD), characteristic of excitatory synapses, occupies the head of a dendritic spine. Isolated postsynaptic densities have been found to contain numerous proteins, including receptors, ion channels, scaffolding proteins, enzymatic signaling molecules, cytoskeletal elements and motor proteins, exocytic and endocytic trafficking proteins, and CAMs (Kennedy 2000; Sheng and Hoogenraad 2007; Harris and Weinberg 2012). Larger spines tend to have larger, more irregularly shaped synapses with a higher density of glutamate receptors (Matsuzaki et al. 2001; Nicholson et al. 2006).

Larger spines are also more likely to contain smooth endoplasmic reticulum, which regulates calcium and integral membrane protein trafficking (Spacek and Harris 1997; CuiWang et al. 2012). In especially large spines, the smooth endoplasmic reticulum forms a spine apparatus, which has Golgi-like functions for posttranslational modification of proteins (Fig. 7) (Spacek and Harris 1997; Pierce et al. 2000; Horton et al. 2005). Larger spines are also more likely to contain polyribosomes, which mediate local protein synthesis (Steward and Schuman 2001; Ostroff et al. 2002; Bourne et al. 2007), and endosomal compartments, which serve local recycling of receptors and membrane management during developmental spine outgrowth and learning-related synaptic plasticity (Cooney et al. 2002; Park et al. 2006). Larger dendritic spines and PSDs are associated with presynaptic axonal boutons, which contain more synaptic vesicles (Harris and Stevens 1989; Lisman and Harris 1993; Harris and Sultan 1995; Shepherd and Harris 1998; Sorra et al. 2006; Bourne et al. 2013). Larger dendritic spines and synapses are also more likely to be associated with perisynaptic astroglial processes (Ventura and Harris 1999; Witcher et al. 2007), which support synapse formation and stabilization, as well as synapse elimination (Clarke and Barres 2013).

These features suggest that larger spines might produce a larger response to glutamate, 

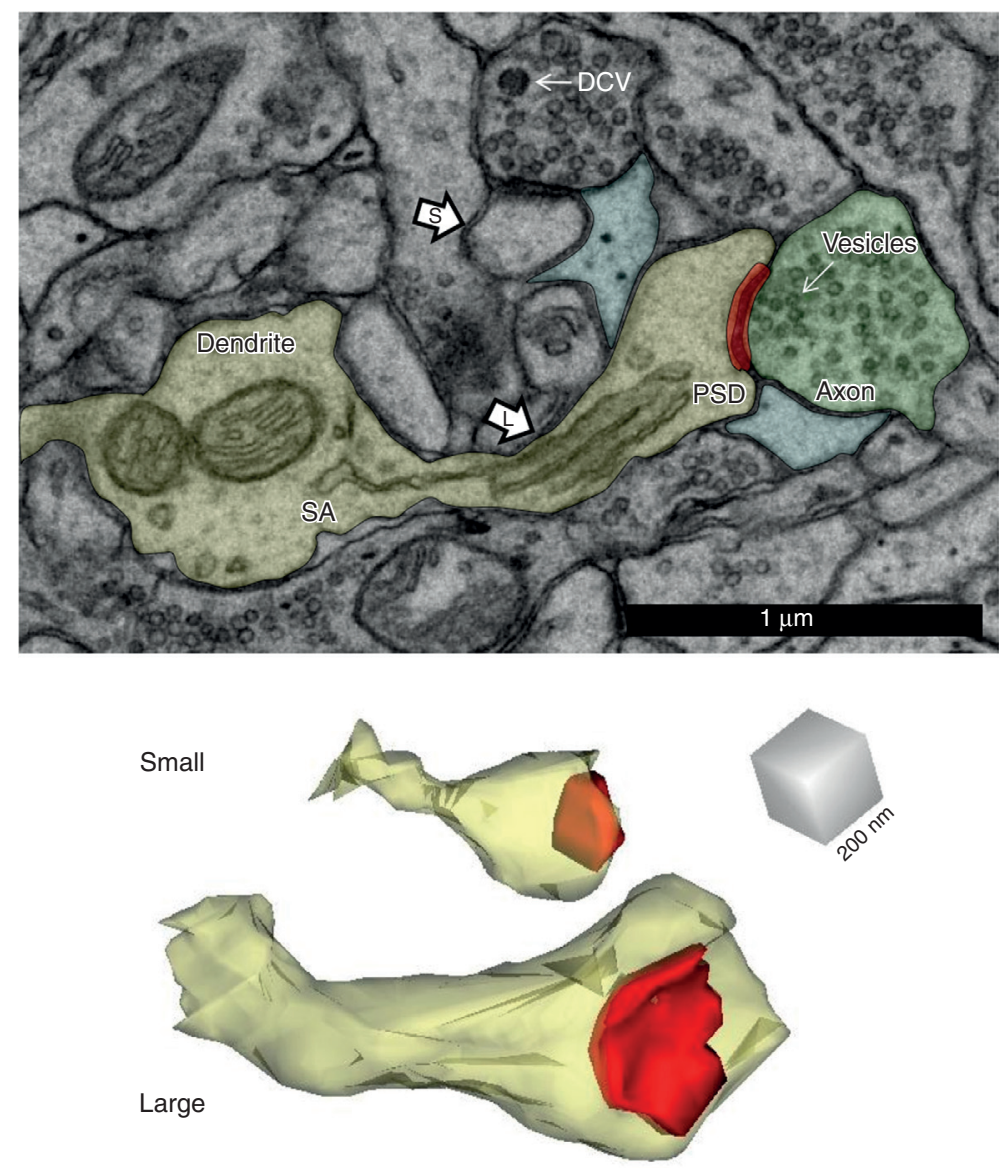

Figure 7. Small and large dendritic spines and associated structures in the mature rat hippocampus. These spines are from the middle of stratum radiatum of area CA1 of a perfusion-fixed preparation. (Top) Electron micrograph (EM) illustrating a small (S) and large (L) dendritic spine, the postsynaptic density (PSD, red) of the large spine, presynaptic axon (green) and vesicles it contains, as well as the perisynaptic astroglial processes (light blue). The presynaptic axon of the small spine also contains a small dense-core vesicle, which is usually associated with transport packets involved in delivering presynaptic active zone proteins to growing synapses. (Bottom) These two spines (yellow) are illustrated in 3D reconstructions with their associated PSDs at the same scale as in the top EMs. DCV, dense-core vesicle; SA, sample area.

released from the presynaptic terminal acting on it, and give rise to local modulation of intracellular calcium, receptor trafficking and recycling, protein translation and degradation, or interaction with perisynaptic astroglia. However, it is rare that any one spine contains all of these features (Cooney et al. 2002). Interestingly, even in the mature hippocampus, $>75 \%$ of all spines are small dendritic spines with head diameters of $<0.6 \mu \mathrm{m}$. These small spines are more prone to rapid formation and elimination depending on age and the conditions of activation (Bourne and Harris 2007, 2011; Macdougall and Fine 2014).

\section{ANALYSIS OF STRUCTURAL PLASTICITY ON DENDRITIC SPINES}

Many studies show that dendritic spine structure is dynamic both under normative conditions in vivo and in response to conditions of synaptic plasticity, which could contribute to 
C.H. Bailey et al.

learning and memory (reviewed in Yuste and Bonhoeffer 2001; Alvarez and Sabatini 2007; Bourne and Harris, 2007, 2008; Rogerson et al. 2014). For example, spatial training (Moser et al. 1997) and exposure to enriched environments (Kozorovitskiy et al. 2005) alters spine number in the hippocampus, and hippocampal-dependent associative learning has been associated with an increase in large dendritic spines sharing the same presynaptic axonal boutons (Geinisman et al. 2001). Hippocampal dendritic spines are also sensitive to estrogens. As a result, overectomized and estrogen-deprived female rats or postmenopausal primates show both cognitive decline and loss of dendritic spines in key cortical areas and/or the hippocampus, both of which are reversed with estrogen-replacement therapy (Foy et al. 2010; Bailey et al. 2011). There are many examples suggesting that different dendritic spines are responsive during different stages and forms of learning and memory. For example, hippocampal dendritic spines seem to be more sensitive during early stages of learning, increasing in number shortly after fear conditioning, whereas cortical neurons appear to acquire more spines later (Restivo et al. 2009). With fear conditioning, spines in the prefrontal association cortex are eliminated, whereas extinction of fear conditioning results in spine formation on the same pyramidal cell dendritic branches (Lai et al. 2012). Hippocampal dendritic spines respond similarly, with neurons active during fear conditioning having fewer dendritic spines (Sanders et al. 2012), and AMPA receptors are preferentially recruited to large hippocampal dendritic spines during fear conditioning (Matsuo et al. 2008). Importantly, these studies provide evidence that the spine remodeling is specific to the synaptic circuits that were active during learning, although they do not rule out involvement of other circuits that were not imaged. Spine shape and number are not necessarily dependable predictors of synapse size, location, or composition (Fiala et al. 1998; Toni et al. 2007; Bock et al. 2011; Shu et al. 2011). A more reliable assessment requires nanoscale $3 \mathrm{D}$ reconstruction from serial section EM, which allows one to understand how changes in structure affect synaptic connectivity and function (Harlow et al. 2001; Denk and Horstmann 2004; Coggan et al. 2005; Toni et al. 2007; Lichtman and Sanes 2008; Meinertzhagen et al. 2009; Cardona et al. 2010; Mishchenko et al. 2010; Ostroff et al. 2010; Bock et al. 2011; Helmstaedter et al. 2011; Bourne and Harris 2012; Cardona 2013; Lu et al. 2013; Wilke et al. 2013). Live imaging with two-photon microscopy also has revealed rapid, activity-dependent turnover of spines, which is common in the neocortex (and, presumably, the hippocampus) during development, but as an animal matures, more of the spines begin to stabilize (Alvarez and Sabatini 2007; Holtmaat and Svoboda 2009). This form of imaging has also revealed dynamic changes in the shapes of individual dendritic spines during the uncaging of glutamate at single spines (Matsuzaki et al. 2001; Kasai et al. 2010, 2004).

Estimates of dendritic spine size and dynamics from live imaging can provide a reasonable first approximation of synapse size in the mature hippocampus because serial section EM reconstruction reveals that spine volume correlates with synaptic area (Harris and Stevens 1987). Thus, spine dynamics readily distinguish stable from unstable spines; however, interpretation of the effect on synaptic connectivity is complicated because of the fact that, during development, excitatory synapses often occur directly on the dendritic shafts of immature but rarely on the shafts of mature spiny hippocampal dendrites (Fiala et al. 1998). In addition, many hippocampal CA1 spines, with apparently mature shapes, can form multiple synapses with different presynaptic axons during development, but multisynaptic CA1 spines are extremely rare in the normal mature hippocampus (Harris et al. 1992; Fiala et al. 1998; Sorra and Harris 2000). In other brain regions, such as the neocortex and thalamus, excitatory, inhibitory, and neuromodulatory synapses can all occur on the same dendritic spine (Spacek and Lieberman 1974; Van Horn et al. 2000).

Finally, crucial subcellular components (such as polyribosomes, smooth endoplasmic reticulum, mitochondria, microtubules, perisynaptic astroglial processes, and presynaptic 
dense-core vesicles) occur at only a small fraction of dendritic spines. Retrospective EM combines light (two-photon) and EM and promises new understanding, although refinement is needed because the reaction products currently used to track the dendrites can obscure synapses and subcellular organelles (Zito et al. 1999; Knott et al. 2006; Nagerl et al. 2007). Despite these caveats, a review of the literature is beginning to reveal a variety of structural components that underlie the initial (5-30 min), intermediate $(\sim 1-2 \mathrm{~h})$, and enduring phases of LTP (reported to last up to a year in vivo [Abraham et al. 2002]), with interesting parallels to learning in the hippocampus (Frey and Morris 1997; Reymann and Frey 2007) and Aplysia, as discussed above.

\section{STRUCTURAL SYNAPTIC PLASTICITY OCCURRING DURING LTP IN THE IMMATURE AND MATURE BRAIN}

Based on molecular, neurophysiological, and structural analyses, the properties of LTP lasting $>3 \mathrm{~h}$ are substantially different from those mediating the first hour of potentiation. Within minutes following the induction of LTP, silent synapses, which are commonly found in the developing nervous system, undergo activation by the insertion or functional modification of AMPA receptors (AMPARs) (Edwards 1991; Isaac et al. 1995; Liao et al. 1995; Durand et al. 1996; Petralia et al. 1999; Malinow et al. 2000; Malinow and Malenka 2002; Groc et al. 2006; Hanse et al. 2009; Macdougall and Fine 2014). Initially, potentiation (or depression) can be sustained by these changes in glutamate receptor properties and composition, but longerlasting potentiation (or depression) involves structural alterations in spines and synapses in both the "immature" (Engert and Bonhoeffer 1999; Maletic-Savatic et al. 1999; Ostroff et al. 2002; Lang et al. 2004; Matsuzaki et al. 2004; Nagerl et al. 2004, 2007; Kopec et al. 2006) and "mature" hippocampus (Van Harreveld and Fifkova 1975; Trommald et al. 1996; Chen et al. 2004; Nagerl et al. 2004; Popov et al. 2004; Zhou et al. 2004; Stewart et al. 2005; Bourne et al. 2007).
Comparison of results from producing LTP in acute slices from P15 and the adult LongEvans rat hippocampus revealed interesting differences, even in such basic findings as spine number and synapse size (Fig. 8). Representative 3D reconstructions illustrate that $\mathrm{P} 15$ dendrites are much less spiny than adult (P55-71) dendrites (Fig. 8A). During LTP, P15 dendrites add spines and synapses, whereas adult dendrites have fewer spines and synapses (Fig. $8 \mathrm{~B})$. In contrast, the small added synapses decreased average synapse size at P15, whereas those in the adult were, on average, larger than during control stimulation (Fig. 8C). Despite these dramatic changes in spine numbers and synapse sizes during LTP, the summed area of synaptic input along the length of dendrites was not altered by LTP at either age. This finding suggests synaptic resources were redistributed to support more spines at P15 and larger synapses in the adults. Interestingly, at P15, total synaptic input has only reached about one third the adult value, which might explain why spine formation predominates during LTP at young ages, whereas spine growth and stabilization predominates in adults. Thus, in the adult hippocampus, control stimulation produces more, smaller, and, presumably, less-effective synapses, whereas LTP results in fewer, larger, and, presumably, more effective synapses (Fig. 8E). These observations are consistent with the hypothesis that synaptic scaling and heterosynaptic competition regulate total synaptic input on a neuron such that limited resources are redistributed to strengthened synapses (Turrigiano and Nelson 2004; Turrigiano 2007; Bourne and Harris 2008; Nelson and Turrigiano 2008; Fiete et al. 2010).

\section{MOLECULAR MECHANISMS UNDERLYING THE STRUCTURAL CHANGES THAT ACCOMPANY SYNAPTIC PLASTICITY PRODUCED BY LTP}

The last two decades have seen a large number of studies using labeled molecules to track their effects with light microscopy on the structural integrity of spines and synapses, largely through the modulation of actin filaments, scaffolding 
C.H. Bailey et al.

A

A $\quad$ P15

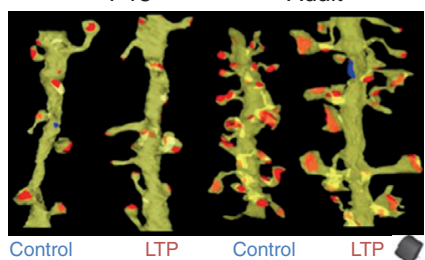

B

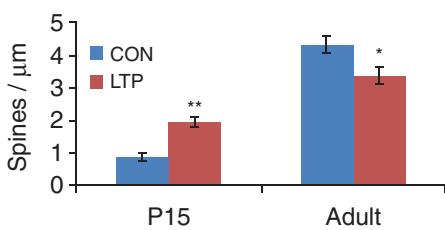

C
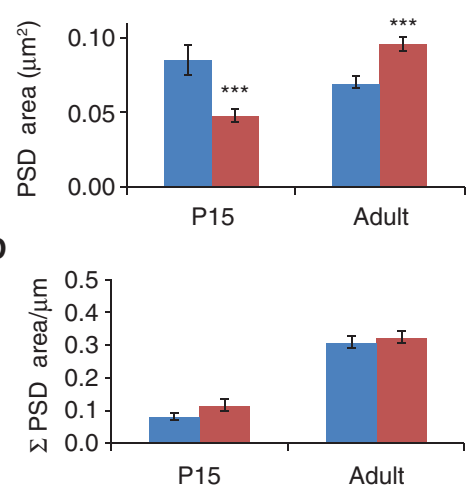

E

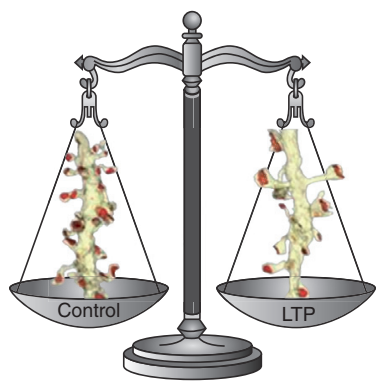

Figure 8. Age differences in the structural correlates of long-term potentiation (LTP) in acute rat hippocampal slices. (A) 3D electron microscopy (EM) of representative dendrites that received control $(\mathrm{CON})$ stimulation versus induction of LTP by $\theta$-burst stimulation (TBS). (B) Opposite effects of TBS on spine density and $(C)$ synaptic surface area (postsynaptic density $[\mathrm{PSD}])$ at $\mathrm{P} 15$ versus adult $(\mathrm{P} 60-70)$ dendrites. $(D)$ Yet, the summed surface area of the synapses per micron length of dendrite was unchanged by LTP at either age. These graphs also illustrate that neither spine density nor summed synapse area has reached adult levels by P15. (E) Thus, as illustrated for adult dendrites, either a dendritic segment supports more, smaller, and presumably less-effective synapses or more, larger, and presumably more-effective synapses.

16 proteins, receptors, and other growth-promoting or -reducing factors at the synapse (Bonhoeffer and Yuste 2002; Ouyang et al. 2005; Alvarez et al. 2007; Sfakianos et al. 2007; Bourne and Harris 2008; Steiner et al. 2008; Loebrich and Nedivi 2009; Budnik and Salinas 2011). Despite dramatic structural plasticity, some synapses show remarkable tenacity (Minerbi et al. 2009), lasting as long as some memories (Xu et al. 2009; Yang et al. 2009). The profound changes in dendritic and synaptic structure and function are also associated with changes in ion channel and receptor density, which are developmentally regulated and are dependent on dendrite caliber and distance from the soma (Maletic-Savatic et al. 1995; Kang et al. 1996; Miyashita and Kubo 1997; Hsia et al. 1998; Magee et al. 1998; Petralia et al. 1999; Rongo and Kaplan 1999; Sans et al. 2000; Molnar et al. 2002; Frick et al. 2003; Bender et al. 2007; Gasparini et al. 2007; Stuart et al. 2008). Recent experiments and computational models suggest that dendritic segments, rather than individual dendritic spines, might be the "minimal units" of synaptic plasticity (Poirazi et al. 2003; Govindarajan et al. 2006, 2011; Losonczy and Magee 2006; Harvey et al. 2008).

In the developing hippocampus, nascent synapses and surface specializations have distinct PSDs, but no presynaptic vesicles (Vaughn 1989; Fiala et al. 1998; Ahmari and Smith 2002). Live imaging and retrospective EM from hippocampal cultures has revealed that small densecore vesicles (DCVs), which carry active zone proteins, are transported to and inserted at nascent synapses, which soon thereafter become functional (Buchanan et al. 1989; Ahmari et al. 2000; Zhai et al. 2001; Shapira and others 2003; Sabo et al. 2006; Tao-Cheng 2007; Zampighi et al. 2008; for review, see Ziv and Garner 2004). This is similar to what is found in Aplysia sensory to motor neuron cocultures, in which time-lapse imaging suggests that rapid activation also turns nascent or silent presynaptic varicosities into active transmitter-releasing sites (Kim et al. 2003). Recent work in mature rat hippocampal slices suggests that the recruitment of presynaptic vesicles to nascent zones of preexisting synapses facilitates a rapid activa- 
tion of silent synaptic regions during LTP (Bell et al. 2014).

Both nascent and active zones of mature hippocampal synapses have a distinct PSD, but unlike the active zone, the presynaptic side of a nascent zone lacks synaptic vesicles (Fig. 9A-D) (Spacek and Harris 1998; Bell et al. 2014). Immunogold labeling has revealed glutamate receptors at the edges of cultured hippocampal synapses (Nair et al. 2013) and in nascent zones of mature hippocampal synapses
(Bell et al. 2014). However, stochastic modeling suggests that falloff in glutamate concentration in the synaptic cleft reduces the probability of glutamate receptor activation from 0.4 at the center of a release site to 0.1 just $200 \mathrm{~nm}$ away (Franks et al. 2002, 2003). The average distance from vesicles docked at active zones to adjacent nascent zones was $\sim 200 \mathrm{~nm}$; hence, the conversion of nascent zones to functional active zones via recruitment of presynaptic vesicles may constitute the initial phase of LTP (Bell et al. 2014).

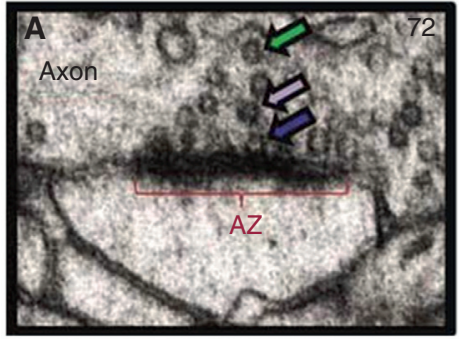

C
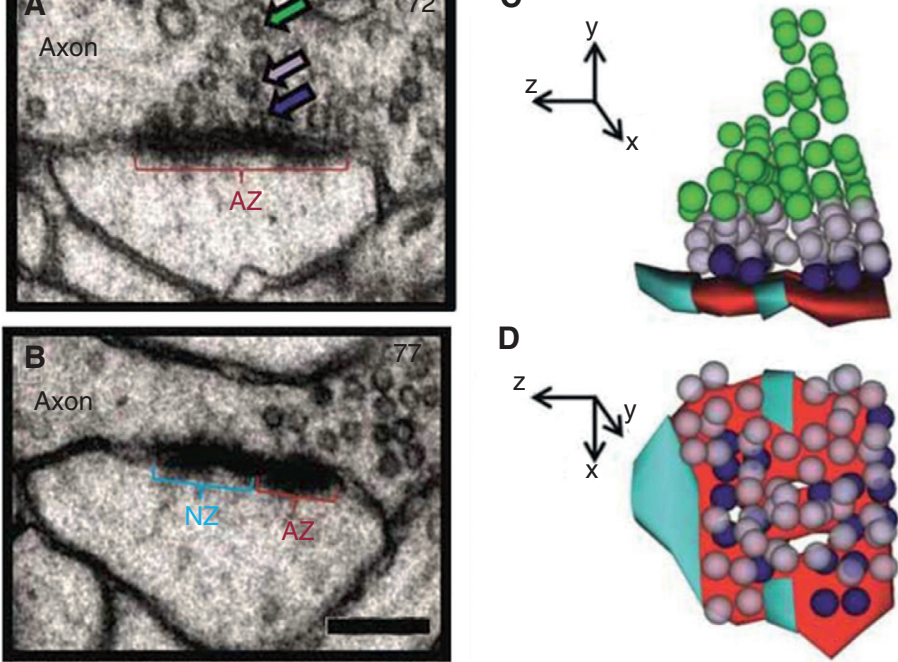

E

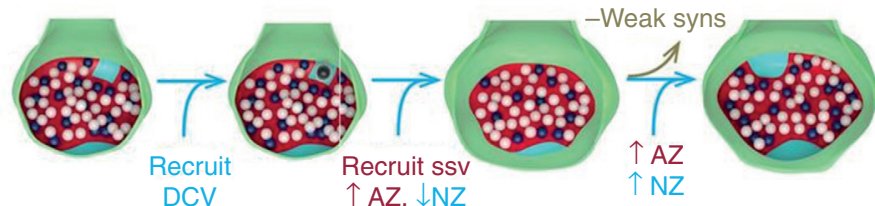

by $5 \mathrm{~min}$

by $30 \mathrm{~min}$

by $2 \mathrm{~h}$

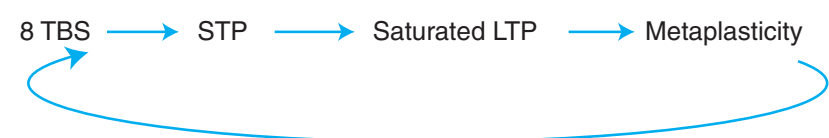

Figure 9. Plasticity of synaptic nascent zones at the edges of synapses from the mature rat hippocampus. $(A-D)$ Electron micrographs (EMs) and 3DEM through representative sections of a synapse to distinguish active zones (AZ, red) from nascent zones (NZ, aqua). Synaptic vesicles are colorized to distinguish docked vesicles (dark blue) from vesicles in a pool within $94 \mathrm{~nm}$ of the presynaptic membrane (light purple) from the reserve pool (green). NZs had no presynaptic vesicles located within $94 \mathrm{~nm}$ perpendicular to them. (E) Model of the sequence of morphological changes associated with different times following the induction of long-term potentiation (LTP) by theta-burst stimulation (TBS), which could participate in the preparation of synapses for subsequent augmentation of LTP. DCV, dense-core vesicle; syns, synapses; ssv, small synaptic vesicle; STP, short-term potentiation. 
C.H. Bailey et al.

This conversion could be facilitated by the insertion of DCVs at existing nascent zones, as DCVs moved into more presynaptic boutons by $5 \mathrm{~min}$ following the induction of LTP, and by $30 \mathrm{~min}$, DCV frequency had returned to control levels, as additional presynaptic vesicles were recruited to nascent zones (Bell et al. 2014). By 2 h, there were fewer small dendritic spines relative to control stimulation in the same slices (Bourne and Harris 2011), and both nascent and active zones were enlarged, potentially, in preparation for synapses to undergo further plasticity (Fig. 9E) (Cao and Harris 2012; Bell et al. 2014).

Support for the hypothesis that DCVs are involved in the initial stages of structural synaptic plasticity comes from analysis of their composition and movements. In addition to active zone proteins, DCVs also transport CAMs (Zhai et al. 2001). CAMs provide bidirectional signaling and coordinated recruitment of preand postsynaptic proteins and receptors (Benson et al. 2000; Sytnyk et al. 2002; Li and Sheng 2003; Scheiffele 2003; Ziv and Garner 2004; Waites et al. 2005; Akins and Biederer 2006; Benson and Huntley 2010). DCVs contain cadherins (Zhai et al. 2001), which cluster at the edges of synapses (Fannon and Colman 1996; Uchida et al. 1996; Elste and Benson 2006), regulate AMPAR trafficking (Zhai et al. 2001; Nuriya and Huganir 2006; Saglietti et al. 2007), and contribute to the stabilization of enhanced synaptic efficacy during LTP (Bozdagi et al. 2000, 2010; Tanaka et al. 2000; Mendez et al. 2010). DCVs could transport other presynaptic CAMs that might play a role in nascent zone conversion. For example, presynaptic neurexin-1 $\beta$ (Nrx-1 $\beta$ ) has two postsynaptic partners, neuroligin-1 (NLG-1) and postsynaptic leucine-rich repeat transmembrane protein 2 (LRRTM2). This extracellular binding modulates presynaptic vesicle release and promotes synapse initiation and stabilization together with $\mathrm{N}$-cadherin (Ichtchenko et al. 1995; Song et al. 1999; Scheiffele et al. 2000; Dean et al. 2003; Graf et al. 2004; Futai et al. 2007; Heine et al. 2008; Sudhof 2008; deWit et al. 2009; Linhoff et al. 2009; Wittenmayer et al. 2009; Stan et al. 2010; Soler-Llavina et al. 2013). Furthermore, the Nrx-1 $\beta /$ NLG-1 complex binds with PSD-95, Stargazin, and other proteins that reduce AMPAR diffusion (Irie et al. 1997; Barrow et al. 2009; Mondin et al. 2011; Giannone et al. 2013). Presynaptic ephrin-B might also participate in nascent zone conversion, as its extracellular binding to postsynaptic EphB receptors has been implicated in the recruitment of presynaptic vesicles, NMDARs, and AMPARs to synapses during maturation and plasticity (Henkemeyer et al. 2003; Kayser et al. 2006; Lim et al. 2008; Klein 2009; Lai and Ip 2009; Nolt et al. 2011; Murata and Constantine-Paton 2013). Whether DCVtransported proteins are engaged in nascent zone conversion and growth at mature hippocampal synapses remains to be determined. However, the aforementioned results from the mature hippocampus provide further links between the early phase of LTP and the remodeling of synapses via regulation of apCAMs during LTF in Aplysia and neural cell-adhesion molecules (NCAMs) during hippocampal learning (Senkov et al. 2006).

Protein synthesis is elevated during periods of synaptogenesis (Phillips et al. 1990; Sebeo et al. 2009), and spines with polyribosomes have enlarged synapses by $2 \mathrm{~h}$ after the induction of LTP following tetanic stimulation in the developing (Ostroff et al. 2002) and mature hippocampus (Bourne et al. 2007). Endosomes and smooth endoplasmic reticulum also play key roles in LTP; however, $<20 \%$ of all dendritic spines contain polyribosomes, endosomes, or smooth endoplasmic reticulum (Spacek and Harris 1997; Cooney et al. 2002; Park et al. 2006, 2008). Even within the dendritic shaft, a single polyribosome or sorting endosome appears to serve 10-20 different dendritic spines (Cooney et al. 2002). This sparse distribution of core structures could be critical in determining where structural plasticity can occur along dendrites.

\section{SYNAPSE GROWTH, METAPLASTICITY, AND THE ADVANTAGE OF SPACED LEARNING}

Some patterns of stimulation have no direct effect on synaptic strength, but instead modulate the subsequent expression of plasticity. 
This phenomenon is known as metaplasticity (Huang et al. 1992; Abraham and Tate 1997; Young and Nguyen 2005). Recently, there has been a surge of interest in testing the effects of spacing episodes of LTP induction as a model for understanding mechanisms of spaced as opposed to distributed learning (Lynch and Gall 2013; Lynch et al. 2013; Wang et al. 2014). Training that is spaced over time produces stronger and longer memories than massed learning, and the efficacy of memory is dependent on the interval between repetitions (Ebbinghaus 1885; Fields 2005). Similarly, if episodes of TBS that initially saturate LTP are spaced by $1 \mathrm{~h}$, more LTP can be induced (Kramar et al. 2012). Interestingly, the number of TBS episodes required to saturate initial LTP, as well as the delay needed between episodes to allow enhanced LTP, is age, strain, and species specific (Cao and Harris 2012). As the prior discussion illustrates, soon after induction, both pre- and postsynaptic processes are recruited to support synapse growth during the later phase of LTP in the mature hippocampus. However, the magnitude of LTP from the first saturating induction was stable. This observation suggests that the growth and formation of nascent zones is a form of metaplasticity because they form without influencing existing synaptic function, but instead they provide a substrate for subsequent LTP (Fig. 9E).

\section{AN OVERALL VIEW AND FUTURE DIRECTIONS}

Perhaps the most striking finding in the cell biology of memory is that the consolidation and long-term storage of memory involves transcription in the nucleus and structural changes at the synapse (Bailey and Kandel 2009). These structural components of learning-related synaptic plasticity can be grouped into two general categories: (1) remodeling and enlargement of preexisting synapses, and (2) alterations in the number of synapses, including both the addition and elimination of synaptic connections (Bailey and Kandel 1993, 2004; Bourne and Harris 2007, 2008).

Studies in Aplysia and the hippocampus have provided evidence that activity-dependent remodeling of preexisting synapses and changes in the number of synapses might play an important role in the expression and storage of information at both the level of individual synaptic connections, as well as in more complex neuronal networks by modulating the activity of the neural network in which this structural plasticity occurs. In both cases, some structural modifications are transient and may contribute to early formative stages of long-term memory, whereas others are more stable, longer lasting, and may confer persistence to the expression of memory storage.

The role of structural synaptic plasticity in memory consolidation raises several questions central to an understanding of how memories are stored in the brain. First, there is the issue of causality versus correlation. Are the structural changes at synapses a consequence of learning, or are they a correlate of learning, or perhaps a purely homeostatic response, or a cellular preparation of new computational space? Second, are memories stored over time in the same synapses? Or are they distributed such that, over time, they can be stored in different synapses so that the system can be efficiently degraded without affecting performance? For the consolidation and persistence of long-term memory, the evidence is quite clear. The same synapses that grow out seem to carry the memory storage. For reconsolidation, the evidence is less clear. There is now evidence that the memory becomes distributed with time, and that the memory can be stored in different synapses of the same neuron so the memory at the systems level can be efficiently degraded without affecting performance. However, reconsolidation can only be activated for a short period of time, usually a few days to a few weeks; thus, the ability to render the memory labile has a limited time window (see Alberini and Kandel 2014). Finally, recent studies suggest the possibility that the long-term memory may not be stored in the synapse, but rather in nuclear programs within the soma. According to this hypothesis, the synaptic changes (both functional and structural) would represent how the storage of each memory is expressed (Chen et al. 2014). Answers to these questions are still being examined in a va- 
C.H. Bailey et al.

riety of memory systems and will provide a more refined understanding of the family of mechanisms that contribute to memory consolidation.

For example, we know that consolidation of explicit memory in mammals at the systems level involves redistribution of the information over new circuits, particularly in the neocortex (Dudai 2012). How is the structural plasticity at the level of individual synapses modified and, perhaps, reorganized to reconfigure the redistributed activity in more expansive neuronal networks following this transfer to the systems level in the cortex?

In vivo imaging reveals subsets of dendritic spines and presynaptic axonal boutons remain highly dynamic in the adult neocortex (Grutzendler et al. 2002; Holtmaat et al. 2005; De Paola et al. 2006; Majewska et al. 2006; Stettler et al. 2006; Lee et al. 2008; for review, see Holtmaat and Svoboda 2009; Hübener and Bonhoeffer 2010). Moreover, recent results show that dramatic spine remodeling, including the formation and stabilization of new spines, can be correlated with the degree of behavioral training and can occur in relevant cortical areas (Xu et al. 2009; Yang et al. 2009; Moczulska et al. 2013).

Although a number of technical hurdles remain, the continuing improvements in optical and molecular approaches raise hope that the ability to visualize, in real time, the synaptic changes that mediate the flow and storage of information in specific neural circuits will come to fruition in the not-too-distant future (Hübener and Bonhoeffer 2010; Mayford et al. 2012). When combined with retrospective $3 \mathrm{D}$ reconstruction from serial section EM of identified synapses, it also should be possible to reveal the fundamental underlying structural and molecular mechanisms of long-term memory expression and storage in complex circuits in different regions of the brain.

\section{REFERENCES}

${ }^{*}$ Reference is also in this collection.

Abraham WC, Bear MF. 1996. Metaplasticity: The plasticity of synaptic plasticity. Trends Neurosci 19: 126-130.

Abraham WC, Huggett A. 1997. Induction and reversal of long-term potentiation by repeated high-frequency stimulation in rat hippocampal slices. Hippocampus 7: $137-145$.

Abraham WC, Tate WP. 1997. Metaplasticity: A new vista across the field of synaptic plasticity. Prog Neurobiol 52: 303-323.

Abraham WC, Mason-Parker SE, Bear MF, Webb S, Tate WP. 2001. Heterosynaptic metaplasticity in the hippocampus in vivo: A BCM-like modifiable threshold for LTP. Proc Natl Acad Sci 98: 10924-10929.

Abraham WC, Logan B, Greenwood JM, Dragunow M. 2002. Induction and experience-dependent consolidation of stable long-term potentiation lasting months in the hippocampus. J Neurosci 22: 9626-9634.

Ahmari SE, Smith SJ. 2002. Knowing a nascent synapse when you see it. Neuron 34: 333-336.

Ahmari SE, Buchanan J, Smith SJ. 2000. Assembly of presynaptic active zones from cytoplasmic transport packets. Nat Neurosci 3: 445-451.

Akins MR, Biederer T. 2006. Cell-cell interactions in synaptogenesis. Curr Opin Neurobiol 16: 83-89.

* Alberini CM, Kandel ER. 2014. The regulation of transcription in memory consolidation. Cold Spring Harb Perspect Biol doi: 110.1101/cshperspect.a021741.

Alberini CM, Ghirardi M, Metz R, Kandel ER. 1994. C/EBP is an immediate-early gene required for the consolidation of long-term facilitation in Aplysia. Cell 76: 1099-1114.

Alvarez VA, Sabatini BL. 2007. Anatomical and physiological plasticity of dendritic spines. Annu Rev Neurosci 30: 7997.

Alvarez VA, Ridenour DA, Sabatini BL. 2007. Distinct structural and ionotropic roles of NMDA receptors in controlling spine and synapse stability. J Neurosci 27: 73657376 .

Bacskai BJ, Hochner B, Mahaut-Smith M, Adams SR, Kaang BK, Kandel ER, Tsien RY. 1993. Spatially resolved dynamics of cAMP and protein kinase A subunits in Aplysia sensory neurons. Science 260: 222-226.

Bailey CH. 1991. Morphological basis of short- and longterm memory in Aplysia. In Perspectives on cognitive neuroscience (ed. Weingartner $\mathrm{H}$, Lister $\mathrm{R}$ ), pp. 76-92. Oxford University Press, New York.

Bailey CH, Chen M. 1983. Morphological basis of long-term habituation and sensitization in Aplysia. Science 220: 91-93.

Bailey CH, Chen M. 1988a. Long-term memory in Aplysia modulates the total number of varicosities of single identified sensory neurons. Proc Natl Acad Sci 85: 2373-2377.

Bailey CH, Chen M. 1988b. Long-term sensitization in Aplysia increases the number of presynaptic contacts onto the identified gill motor neuron L7. Proc Natl Acad Sci 85: 9356-9359.

Bailey CH, Chen M. 1989. Time course of structural changes at identified sensory neuron synapses during long-term sensitization in Aplysia. J Neurosci 9: 1774-1780.

Bailey CH, Chen M. 1990. Morphological alterations at identified sensory neuron synapses during long-term sensitization in Aplysia. In The biology of memory, Vol. 23. Symposium Medicum Hoechst (ed. Squire L, Lindenlaub E), pp. 135-153. Schattauer, Stuttgart, Germany.

Bailey CH, Kandel ER. 1985. Molecular approaches to the study of short-term and long-term memory. In Functions 
of the brain (ed. Coen CW), pp. 98-129. Clarendon, Oxford.

Bailey CH, Kandel ER. 1993. Structural changes accompanying memory storage. Annu Rev Physiol 55: 397-426.

Bailey CH, Kandel ER. 2004. Synaptic growth and the persistence of long-term memory: A molecular perspective. In The new cognitive neurosciences (ed. Gazzaniga MS), Vol. III, pp. 647-664. MIT Press, Cambridge, MA.

Bailey CH, Kandel ER. 2008a. Synaptic remodeling, synaptic growth and the storage of long-term memory in Aplysia. In The essence of memory, progress in brain research (ed. Sossin W, et al.), pp. 179-198. Elsevier, Amsterdam.

Bailey CH, Kandel ER. 2008b. Activity-dependent remodeling of presynaptic boutons. In New encyclopedia of neuroscience (ed. Squire L), pp. 67-74. Elsevier, Amsterdam.

Bailey CH, Kandel ER. 2009. Synaptic and cellular basis of learning. In Handbook of neuroscience for behavioral sciences (ed. Cacioppo JT, Berntson GG), Vol. 1, Chap. 27, pp. 528-551. Wiley, New York.

Bailey CH, Thompson EB, Castellucci VF, Kandel ER. 1979. Ultrastructure of the synapses of sensory neurons that mediate the gill-withdrawal reflex in Aplysia. J Neurocytol 8: $415-444$.

Bailey CH, Chen M, Keller F, Kandel ER. 1992a. Serotoninmediated endocytosis of apCAM: An early step of learning-related synaptic growth in Aplysia. Science 25: $645-$ 649.

Bailey CH, Montarolo PG, Chen M, Kandel ER, Schacher S. 1992b. Inhibitors of protein and RNA synthesis block the structural changes that accompany long-term heterosynaptic plasticity in the sensory neurons of Aplysia. Neuron 9: 749-758.

Bailey CH, Bartsch D, Kandel ER. 1996. Toward a molecular definition of long-term memory storage. Proc Natl Acad Sci 93: 13445-13452.

Bailey CH, Kaang BK, Chen M, Marin C, Lim A, Kandel ER. 1997. Mutation in the phosphorylation sites of MAP kinase blocks learning-related internalization of apCAM in Aplysia sensory neurons. Neuron 18: 913-924.

Bailey CH, Kandel ER, Si K. 2004. The persistence of longterm memory: A molecular approach to self-sustaining changes in learning-induced synaptic growth. Neuron 44: 49-57.

Bailey CH, Kandel ER, Si K, Choi YB. 2005. Toward a molecular biology of learning-related synaptic growth in Aplysia. Cell Sci Rev 2: 27-57.

Bailey CH, Barco A, Hawkins RD, Kandel ER. 2008. Molecular studies of learning and memory in Aplysia and the hippocampus: A comparative analysis of implicit and explicit memory storage. In Learning and memory: Comprehensive reference, Vol 4. Molecular mechanisms of memory (ed. Byrne JH), pp. 11-29. Elsevier, Amsterdam.

Bailey ME, Wang AC, Hao J, Janssen WG, Hara Y, Dumitriu D, Hof PR, Morrison JH. 2011. Interactive effects of age and estrogen on cortical neurons: Implications for cognitive aging. Neuroscience 191: 148-158.

Barnes CA, Jung MW, McNaughton BL, Korol DL, Andreasson K, Worley PF. 1994. LTP saturation and spatial learning disruption: Effects of task variables and saturation levels. J Neurosci 14: 5793-5806.
Barrow SL, Constable JR, Clark E, El-Sabeawy F, McAllister AK, Washbourne P. 2009. Neuroligin1: A cell adhesion molecule that recruits PSD-95 and NMDA receptors by distinct mechanisms during synaptogenesis. Neural Dev 4: 17.

Bell ME, Bourne JN, Chirillo MA, Harris KM. 2014. Conversion of nascent to active zones as synapses enlarge during long-term potentiation in mature hippocampus. J Comp Neurol 522: 3861-3884.

Bender RA, Kirschstein T, Kretz O, Brewster AL, Richichi C, Ruschenschmidt C, Shigemoto R, Beck H, Frotscher M, Baram TZ. 2007. Localization of HCN1 channels to presynaptic compartments: Novel plasticity that may contribute to hippocampal maturation. J Neurosci 27: 4697 4706.

Benson DL, Huntley GW. 2010. Building and remodeling synapses. Hippocampus 22: 954-968.

Benson DL, Schnapp LM, Shapiro L, Huntley GW. 2000. Making memories stick: Cell-adhesion molecules in synaptic plasticity. Trends Cell Biol 10: 473-482.

Bliss TV, Collingridge GL, Morris RG. 2013. Synaptic plasticity in health and disease: Introduction and overview. Philos Trans R Soc Lond B Biol Sci 369: 20130129.

Bock DD, Lee WC, Kerlin AM, Andermann ML, Hood G, Wetzel AW, Yurgenson S, Soucy ER, Kim HS, Reid RC. 2011. Network anatomy and in vivo physiology of visual cortical neurons. Nature 471: 177-182.

Bonhoeffer T, Yuste R. 2002. Spine motility. Phenomenology, mechanisms, and function. Neuron 35: 1019-1027.

Bourne J, Harris KM. 2007. Do thin spines learn to be mushroom spines that remember? Curr Opin Neurobiol 17: $381-386$.

Bourne JN, Harris KM. 2008. Balancing structure and function at hippocampal dendritic spines. Annu Rev Neurosci 31: $47-67$

Bourne JN, Harris KM. 2011. Coordination of size and number of excitatory and inhibitory synapses results in a balanced structural plasticity along mature hippocampal CA1 dendrites during LTP. Hippocampus 21: 354373.

Bourne JN, Harris KM. 2012. Nanoscale analysis of structural synaptic plasticity. Curr Opin Neurobiol 22: 372382.

Bourne JN, Sorra KE, Hurlburt J, Harris KM. 2007. Polyribosomes are increased in spines of CA1 dendrites $2 \mathrm{~h}$ after the induction of LTP in mature rat hippocampal slices. Hippocampus 17: 1-4.

Bourne JN, Chirillo MA, Harris KM. 2013. Presynaptic ultrastructural plasticity along $\mathrm{CA} 3 \rightarrow \mathrm{CA} 1$ axons during LTP in mature hippocampus. J Comp Neurol 521: 38983912.

Bowden JB, Abraham WC, Harris KM. 2012. Differential effects of strain, circadian cycle, and stimulation pattern on LTP and concurrent LTD in the dentate gyrus of freely moving rats. Hippocampus 22: 1363-1370.

Bozdagi O, Shan W, Tanaka H, Benson DL, Huntley GW. 2000. Increasing numbers of synaptic puncta during late-phase LTP: N-cadherin is synthesized, recruited to synaptic sites, and required for potentiation. Neuron 28: $245-259$. 
C.H. Bailey et al.

Bozdagi O, Wang XB, Nikitczuk JS, Anderson TR, Bloss EB, Radice GL, Zhou Q, Benson DL, Huntley GW. 2010. Persistence of coordinated long-term potentiation and dendritic spine enlargement at mature hippocampal CA1 synapses requires N-cadherin. J Neurosci 30: $9984-$ 9989.

Buchanan J, Sun YA, Poo MM. 1989. Studies of nerve-muscle interactions in Xenopus cell culture: Fine structure of early functional contacts. J Neurosci 9: 1540-1554.

Budnik V, Salinas PC. 2011. Wnt signaling during synaptic development and plasticity. Curr Opin Neurobiol 21: 151-159.

Buzsaki G. 2002. $\theta$ Oscillations in the hippocampus. Neuron 33: $325-340$.

Buzsaki G, Haas HL, Anderson EG. 1987. Long-term potentiation induced by physiologically relevant stimulus patterns. Brain Res 435: 331-333.

Cao G, Harris KM. 2012. Developmental regulation of the late phase of long-term potentiation (L-LTP) and metaplasticity in hippocampal area CAl of the rat. J Neurophysiol 107: 902-912.

Cardona A. 2013. Towards semi-automatic reconstruction of neural circuits. Neuroinformatics 11: 31-33.

Cardona A, Saalfeld S, Preibisch S, Schmid B, Cheng A, Pulokas J, Tomancak P, Hartenstein V. 2010. An integrated micro- and macroarchitectural analysis of the Drosophila brain by computer-assisted serial section electron microscopy. PLoS Biol 8: e1000502.

Casadio A, Martin KC, Giustetto M, Zhu H, Chen M, Bartsch D, Bailey CH, Kandel ER. 1999. A transient, neuron-wide form of CREB-mediated long-term facilitation can be stabilized at specific synapses by local protein synthesis. Cell 99: 221-237.

Castellucci V, Pinsker H, Kupfermann I, Kandel ER. 1970. Neuronal mechanisms of habituation and dishabituation of the gill-withdrawal reflex in Aplysia. Science 167: 1745-1748.

Castellucci VF, Blumenfeld H, Goelet P, Kandel ER. 1989. Inhibitor of protein synthesis blocks long-term behavioral sensitization in the isolated gill-withdrawal reflex of Aplysia. Science 220: 91-93.

Chen YC, Bourne J, Pieribone VA, Fitzsimonds RM. 2004. The role of actin in the regulation of dendritic spine morphology and bidirectional synaptic plasticity. NeuroReport 15: 829-832.

Chen S, Cai D, Pearce K, Sun PYW, Roberts AC, Glanzman DL. 2014. Reinstatement of long-term memory following erasure of its behavioral and synaptic expression in Aplysia. eLife 3: $\mathrm{e} 03896$.

Choi Y-B, Li H-L, Kassabov SR, Jin I, Puthanveettil SV, Karl KA, Lu Y, Kim J-H, Bailey CH, Kandel ER. 2011. Neurexin-Neuroligin transsynaptic interaction mediates learning-related synaptic remodeling and long-term facilitation in Aplysia. Neuron 70: 1-14.

Clarke LE, Barres BA. 2013. Emerging roles of astrocytes in neural circuit development. Nat Rev Neurosci 14: 311 321.

Coggan JS, Bartol TM, Esquenazi E, Stiles JR, Lamont S, Martone ME, Berg DK, Ellisman MH, Sejnowski TJ. 2005. Evidence for ectopic neurotransmission at a neuronal synapse. Science 309: 446-451.
Cooney JR, Hurlburt JL, Selig DK, Harris KM, Fiala JC. 2002. Endosomal compartments serve multiple hippocampal dendritic spines from a widespread rather than a local store of recycling membrane. J Neurosci 22: 22152224.

Cui-Wang T, Hanus C, Cui T, Helton T, Bourne J, Watson D, Harris KM, Ehlers MD. 2012. Local zones of endoplasmic reticulum complexity confine cargo in neuronal dendrites. Cell 148: 309-321.

Dean C, Scholl FG, Choih J, DeMaria S, Berger J, Isacoff E, Scheiffele P. 2003. Neurexin mediates the assembly of presynaptic terminals. Nat Neurosci 6: 708-716.

Denk W, Horstmann H. 2004. Serial block-face scanning electron microscopy to reconstruct three-dimensional tissue nanostructure. PLoS Biol 2: e329.

De Paola V, Holtmaat A, Knott G, Song S, Wilbrecht L, Caroni P, Svoboda K. 2006. Cell type-specific structural plasticity of axonal branches and boutons in the adult neocortex. Neuron 49: 861-875.

deWit J, Sylwestrak E, O'Sullivan ML, Otto S, Tiglio K, Savas JN, Yates JR III, Comoletti D, Taylor P, Ghosh A. 2009. LRRTM2 interacts with Neurexin1 and regulates excitatory synapse formation. Neuron 64: 799-806.

Diana G, Domenici MR, Loizzo A, Scotti de Carolis A, Sagratella S. 1994. Age and strain differences in rat place learning and hippocampal dentate gyrus frequency-potentiation. Neurosci Lett 171: 113-116.

Dudai Y. 2012. The restless engram: Consolidations never end. Annu Rev Neurosci 35: 227-247.

Durand GM, Kovalchuk Y, Konnerth A. 1996. Long-term potentiation and functional synapse induction in developing hippocampus. Nature 381: 71-75.

Ebbinghaus H. 1885. Über das gedächnis: Untersuchungen zur experimentellen psychologie [Memory: A contribution to experimental psychology]. Veit, Leipzig, Germany.

Edwards F. 1991. Neurobiology. LTP is a long-term problem. Nature 350: 271-272.

Elste AM, Benson DL. 2006. Structural basis for developmentally regulated changes in cadherin function at synapses. J Comp Neurol 495: 324-335.

Engert F, Bonhoeffer T. 1999. Dendritic spine changes associated with hippocampal long-term synaptic plasticity. Nature 399: 66-70.

Fannon AM, Colman DR. 1996. A model for central synaptic junctional complex formation based on the differential adhesive specificities of the cadherins. Neuron 17: 423-434.

Fiala JC, Feinberg M, Popov V, Harris KM. 1998. Synaptogenesis via dendritic filopodia in developing hippocampal area CA1. J Neurosci 18: 8900-8911.

Fields RD. 2005. Making memories stick. Sci Am 292: $75-$ 81.

Fiete IR, Senn W, Wang CZ, Hahnloser RH. 2010. Spiketime-dependent plasticity and heterosynaptic competition organize networks to produce long scale-free sequences of neural activity. Neuron 65: 563-576.

Foy MR, Baudry M, Akopian GK, Thompson RF. 2010. Regulation of hippocampal synaptic plasticity by estrogen and progesterone. Vitam Horm 82: 219-239. 
Franks KM, Bartol TM Jr, Sejnowski TJ. 2002. A Monte Carlo model reveals independent signaling at central glutamatergic synapses. Biophys J 83: 2333-2348.

Franks KM, Stevens CF, Sejnowski TJ. 2003. Independent sources of quantal variability at single glutamatergic synapses. J Neurosci 23: 3186-3195.

Frey U, Morris RG. 1997. Synaptic tagging and long-term potentiation. Nature 385: 533-536.

Frey U, Schollmeier K, Reymann KG, Seidenbecher T. 1995. Asymptotic hippocampal long-term potentiation in rats does not preclude additional potentiation at later phases. Neuroscience 67: 799-807.

Frick A, Magee J, Koester HJ, Migliore M, Johnston D. 2003. Normalization of $\mathrm{Ca}^{2+}$ signals by small oblique dendrites of CA1 pyramidal neurons. J Neurosci 23: 3243-3250.

Frost WN, Castellucci VF, Hawkins RD, Kandel ER. 1985. Monosynaptic connections made by the sensory neurons of the gill- and siphon-withdrawal reflex in Aplysia participates in the storage of long-term memory for sensitization. Proc Natl Acad Sci 82: 8266-8269.

Futai K, Kim MJ, Hashikawa T, Scheiffele P, Sheng M, Hayashi Y. 2007. Retrograde modulation of presynaptic release probability through signaling mediated by PSD-95neuroligin. Nat Neurosci 10: 186-195.

Gasparini S, Losonczy A, Chen X, Johnston D, Magee JC. 2007. Associative pairing enhances action potential backpropagation in radial oblique branches of CA1 pyramidal neurons. J Physiol 580: 787-800.

Geinisman Y, Berry RW, Disterhoft JF, Power JM, van der Zee EA. 2001. Associative learning elicits the formation of multiple-synapse boutons. J Neurosci 21: 5568-5573.

Ghirardi M, Montarolo PG, Kandel ER. 1995. A novel intermediate stage in the transition between short- and long-term facilitation in the sensory to motor neuron synapse of Aplysia. Neuron 14: 413-420.

Giannone G, Mondin M, Grillo-Bosch D, Tessier B, SaintMichel E, Czondor K, Sainlos M, Choquet D, Thoumine O. 2013. Neurexin-1 $\beta$ binding to neuroligin-1 triggers the preferential recruitment of PSD-95 versus gephyrin through tyrosine phosphorylation of neuroligin-1. Cell Rep 3: 1996-2007.

Glanzman DL, Kandel ER, Schacher S. 1990. Target-dependent structural changes accompanying long-term synaptic facilitation in Aplysia neurons. Science 249: 779-802.

Govindarajan A, Kelleher RJ, Tonegawa S. 2006. A clustered plasticity model of long-term memory engrams. Nat Rev Neurosci 7: 575-583.

Govindarajan A, Israely I, Huang SY, Tonegawa S. 2011. The dendritic branch is the preferred integrative unit for protein synthesis-dependent LTP. Neuron 69: 132-146.

Graf ER, Zhang X, Jin SX, Linhoff MW, Craig AM. 2004. Neurexins induce differentiation of GABA and glutamate postsynaptic specializations via neuroligins. Cell 119: $1013-1026$.

Greenough WT, Bailey CH. 1988. The anatomy of a memory: Convergence of results across a diversity of tests. Trends Neurosci 11: 142-147.

Groc L, Gustafsson B, Hanse E. 2006. AMPA signalling in nascent glutamatergic synapses: There and not there! Trends Neurosci 29: 132-139.
Grutzendler J, Kasthuri N, Gan WB. 2002. Long-term dendritic spine stability in the adult cortex. Nature 420: 812 816.

Habib D, Tsui CK, Rosen LG, Dringenberg HC. 2013. Occlusion of low-frequency-induced, heterosynaptic longterm potentiation in the rat hippocampus in vivo following spatial training. Cereb Cortex 24: 3090-3096.

Han JH, Lim YS, Kandel ER, Kaang BK. 2004. Role of Aplysia cell adhesion molecules during 5-HT-induced longterm functional and structural changes. Learn Mem 11: 421-435.

Hanse E, Taira T, Lauri S, Groc L. 2009. Glutamate synapse in developing brain: An integrative perspective beyond the silent state. Trends Neurosci 32: 532-537.

Harlow ML, Ress D, Stoschek A, Marshall RM, McMahan UJ. 2001. The architecture of active zone material at the frog's neuromuscular junction. Nature 409: 479-484.

Harris KM, Kater SB. 1994. Dendritic spines: Cellular specializations imparting both stability and flexibility to synaptic function. Annu Rev Neurosci 17: 341-371.

Harris KM, Stevens JK. 1987. Study of dendritic spines by serial electron microscopy and three-dimensional reconstructions. Neurol Neurobiol 37: 179-199.

Harris KM, Stevens JK. 1989. Dendritic spines of CA1 pyramidal cells in the rat hippocampus: Serial electron microscopy with reference to their biophysical characteristics. J Neurosci 9: 2982-2997.

Harris KM, Sultan P. 1995. Variation in the number, location and size of synaptic vesicles provides an anatomical basis for the nonuniform probability of release at hippocampal CA1 synapses. Neuropharmacology 34: 1387-1395.

Harris KM, Teyler TJ. 1983. Age differences in a circadian influence on hippocampal LTP. Brain Res 261: 69-73.

Harris KM, Weinberg RJ. 2012. Ultrastructure of synapses in the mammalian brain. Cold Spring Harb Perspect Biol 4: a005587.

Harris KM, Jensen FE, Tsao B. 1992. Three-dimensional structure of dendritic spines and synapses in rat hippocampus (CA1) at postnatal day 15 and adult ages: Implications for the maturation of synaptic physiology and long-term potentiation. J Neurosci 12: 2685-2705.

Harvey CD, Yasuda R, Zhong H, Svoboda K. 2008. The spread of Ras activity triggered by activation of a single dendritic spine. Science 321: 136-140.

Hatada Y, Wu F, Sun ZY, Schacher S, Goldberg DJ. 2000. Presynaptic morphological changes associated with long-term synaptic facilitation are triggered by actin polymerization at preexisting varicosities. J Neurosci 20: RC82.

Hawkins RD, Kandel ER, Bailey CH. 2006. Molecular mechanisms of memory storage in Aplysia. Biol Bull 210: 174191.

Hawkins RD, Kandel ER, Jin I. 2012. Possible roles of spontaneous transmitter release in homeostasis and growth related plasticity at Aplysia sensory-motor neuron synapses. In Molluscan neuroscience in the genomic era: From gastropods to cephalopods, Abstract 294.06. Scripps Research Institute, Jupiter, FL.

Heine M, Thoumine O, Mondin M, Tessier B, Giannone G, Choquet D. 2008. Activity-independent and subunitspecific recruitment of functional AMPA receptors at 
C.H. Bailey et al.

neurexin/neuroligin contacts. Proc Natl Acad Sci 105: 20947-20952.

Helmstaedter M, Briggman KL, Denk W. 2011. High-accuracy neurite reconstruction for high-throughput neuroanatomy. Nat Neurosci 14: 1081-1088.

Henkemeyer M, Itkis OS, Ngo M, Hickmott PW, Ethell IM. 2003. Multiple EphB receptor tyrosine kinases shape dendritic spines in the hippocampus. J Cell Biol 163: 13131326.

Holtmaat A, Svoboda K. 2009. Experience-dependent structural synaptic plasticity in the mammalian brain. Nat Rev Neurosci 10: 647-658.

Holtmaat AJ, Trachtenberg JT, Wilbrecht L, Shepherd GM, Zhang X, Knott GW, Svoboda K. 2005. Transient and persistent dendritic spines in the neocortex in vivo. $\mathrm{Neu}$ ron 45: 279-291.

Horton AC, Racz B, Monson EE, Lin AL, Weinberg RJ, Ehlers MD. 2005. Polarized secretory trafficking directs cargo for asymmetric dendrite growth and morphogenesis. Neuron 48: 757-771.

Hsia AY, Malenka RC, Nicoll RA. 1998. Development of excitatory circuitry in the hippocampus. J Neurophysiol 79: 2013-2024.

Huang YY, Kandel ER. 1994. Recruitment of long-lasting and protein kinase A-dependent long-term potentiation in the CA1 region of hippampus requires repeated tetanization. Learn Mem 1: 74-82.

Huang YY, Colino A, Selig DK, Malenka RC. 1992. The influence of prior synaptic activity on the induction of long-term potentiation. Science 255: 730-733.

Hübener M, Bonhoeffer T. 2010. Searching for engrams. Neuron 67: 363-371.

Hyman JM, Wyble BP, Goyal V, Rossi CA, Hasselmo ME. 2003. Stimulation in hippocampal region CA1 in behaving rats yields long-term potentiation when delivered to the peak of $\theta$ and long-term depression when delivered to the trough. J Neurosci 23: 11725-11731.

Ichtchenko K, Hata Y, Nguyen T, Ullrich B, Missler M, Moomaw C, Sudhof TC. 1995. Neuroligin 1: A splice sitespecific ligand for $\beta$-neurexins. Cell 81: 435-443.

Irie M, Hata Y, Takeuchi M, Ichtchenko K, Toyoda A, Hirao K, Takai Y, Rosahl TW, Sudhof TC. 1997. Binding of neuroligins to PSD-95. Science 277: 1511-1515.

Isaac JT, Nicoll RA, Malenka RC. 1995. Evidence for silent synapses: Implications for the expression of LTP. Neuron 15: $427-434$.

Jessell TM, Kandel ER. 1993. Synaptic transmission: A bidirectional and self-modifiable form of cell-cell communication. Cell 72 (Suppl): 1-30.

Jin I, Puthanveettil S, Udo H, Karl K, Kandel ER, Hawkins RD. 2012a. Spontaneous transmitter release is critical for the induction of long-term and intermediate-term facilitation in Aplysia. Proc Natl Acad Sci 109: 9131-9136.

Jin I, Udo H, Rayman JB, Puthanveettil S, Kandel ER, Hawkins RD. 2012b. Spontaneous transmitter release recruits postsynaptic mechanisms of long-term and intermediate-term facilitation in Aplysia. Proc Natl Acad Sci 109: 9137-9142.

Kandel ER. 2001. The molecular biology of memory storage: A dialogue between genes and synapses. Science 294: $1030-1038$.
Kandel ER. 2009. The biology of memory: A forty-year perspective. J Neurosci 29: 12748-12756.

Kang J, Huguenard JR, Prince DA. 1996. Development of BK channels in neocortical pyramidal neurons. J Neurophysiol 76: $188-198$.

Kasai H, Fukuda M, Watanabe S, Hayashi-Takagi A, Noguchi J. 2010. Structural dynamics of dendritic spines in memory and cognition. Trends Neurosci 33: 121-129.

Kassabov SR, Choi YB, Karl KA, Vishwasrao HD, Bailey CH, Kandel ER. 2013. A single Aplysia neurotrophin mediates synaptic facilitation via differentially processed isoforms secreted as mature or precursor forms. Cell Rep 3: 1-15.

Kayser MS, McClelland AC, Hughes EG, Dalva MB. 2006. Intracellular and transsynaptic regulation of glutamatergic synaptogenesis by EphB receptors. J Neurosci 26: 12152-12164.

Kelleher RJ, Govindarajan A, Tonegawa S. 2004. Translational regulatory mechanisms in persistent forms of synaptic plasticity. Neuron 44: 59-73.

Kennedy MB. 2000. Signal-processing machines at the postsynaptic density. Science 290: 750-754.

Kim JH, Udo H, Li HL, Youn TY, Chen M, Kandel ER, Bailey CH. 2003. Presynaptic activation of silent synapses and growth of new synapses contribute to intermediate and long-term facilitation in Aplysia. Neuron 40: 151-165.

Klein R. 2009. Bidirectional modulation of synaptic functions by Eph/ephrin signaling. Nat Neurosci 12: 15-20.

Knott GW, Holtmaat A, Wilbrecht L, Welker E, Svoboda K. 2006. Spine growth precedes synapse formation in the adult neocortex in vivo. Nat Neurosci 9: 1117-1124.

Kopec CD, Li B, Wei W, Boehm J, Malinow R. 2006. Glutamate receptor exocytosis and spine enlargement during chemically induced long-term potentiation. J Neurosci 26: $2000-2009$.

Kozorovitskiy Y, Gross CG, Kopil C, Battaglia L, McBreen M, Stranahan AM, Gould E. 2005. Experience induces structural and biochemical changes in the adult primate brain. Proc Natl Acad Sci 102: 17478-17482.

Kramar EA, Babayan AH, Gavin CF, Cox CD, Jafari M, Gall CM, Rumbaugh G, Lynch G. 2012. Synaptic evidence for the efficacy of spaced learning. Proc Natl Acad Sci 109: 5121-5126.

Lai KO, Ip NY. 2009. Synapse development and plasticity: Roles of ephrin/Eph receptor signaling. Curr Opin Neurobiol 19: 275-283.

Lai CS, Franke TF, Gan WB. 2012. Opposite effects of fear conditioning and extinction on dendritic spine remodelling. Nature 483: 87-91.

Lang C, Barco A, Zablow L, Kandel ER, Siegelbaum SA, Zakharenko SS. 2004. Transient expansion of synaptically connected dendritic spines upon induction of hippocampal long-term potentiation. Proc Natl Acad Sci 101: 16665-16670.

Lee SH, Lim CS, Park H, Lee JA, Han JH, Kim H, Cheang YH, Lee SH, Lee YS, Ko HG, et al. 2007. Nuclear translocation of CAM-associated protein activates transcription for long-term facilitation in Aplysia. Cell 129: 801812.

Lee WC, Chen JL, Huang H, Leslie JH, Amitai Y, So PT, Nedivi E. 2008. A dynamic zone defines interneuron re- 
modeling in the adult neocortex. Proc Natl Acad Sci 105: 19968-19973.

Lee SH, Shim J, Choi SL, Lee N, Lee CH, Bailey CH, Kandel ER, Jang DJ, Kaang BK. 2012. Learning-related synaptic growth mediated by internalization of Aplysia cell adhesion molecule is controlled by membrane phosphatidylinositol 4,5-bisphosphate synthetic pathway. J Neuroscience 32: 16296-16305.

Leinekugel X, Khazipov R, Cannon R, Hirase H, Ben-Ari Y, Buzsaki G. 2002. Correlated bursts of activity in the neonatal hippocampus in vivo. Science 296: 2049-2052.

Li Z, Sheng M. 2003. Some assembly required: The development of neuronal synapses. Nat Rev Mol Cell Biol 4: 833-841.

Li H-L, Huang BS, Vishwasrao H, Sutedja N, Chen W, Jin I, Hawkins RD, Bailey CH, Kandel ER. 2009. Dscam mediates remodeling of glutamate receptors in Aplysia during de novo and learning-related synapse formation. Neuron 61: 527-540.

Liao D, Hessler NA, Malinow R. 1995. Activation of postsynaptically silent synapses during pairing-induced LTP in CA1 region of hippocampal slice. Nature 375: 400404.

Lichtman JW, Sanes JR. 2008. Ome sweet ome: What can the genome tell us about the connectome? Curr Opin Neurobiol 18: 346-353.

Lim BK, Matsuda N, Poo MM. 2008. Ephrin-B reverse signaling promotes structural and functional synaptic maturation in vivo. Nat Neurosci 11: 160-169.

Linhoff MW, Lauren J, Cassidy RM, Dobie FA, Takahashi H, Nygaard HB, Airaksinen MS, Strittmatter SM, Craig AM. 2009. An unbiased expression screen for synaptogenic proteins identifies the LRRTM protein family as synaptic organizers. Neuron 61: 734-749.

Lisman J, Harris KM. 1993. Quantal analysis and synaptic anatomy-Integrating two views of hippocampal plasticity. Trends Neurosci 16: 141-147.

Loebrich S, Nedivi E. 2009. The function of activity-regulated genes in the nervous system. Physiol Rev 89: 10791103.

Losonczy A, Magee JC. 2006. Integrative properties of radial oblique dendrites in hippocampal CA1 pyramidal neurons. Neuron 50: 291-307.

Lu W, Bushong EA, Shih TP, Ellisman MH, Nicoll RA. 2013. The cell-autonomous role of excitatory synaptic transmission in the regulation of neuronal structure and function. Neuron 78: 433-439.

Lynch G, Gall CM. 2013. Mechanism based approaches for rescuing and enhancing cognition. Front Neurosci 7: 143.

Lynch G, Kramar EA, Babayan AH, Rumbaugh G, Gall CM. 2013. Differences between synaptic plasticity thresholds result in new timing rules for maximizing long-term potentiation. Neuropharmacology 64: 27-36.

Macdougall MJ, Fine A. 2014. The expression of long-term potentiation: Reconciling the priests and the positivists. Philos Trans R Soc Lond B Biol Sci 369: 20130135.

Magee J, Hoffman D, Colbert C, Johnston D. 1998. Electrical and calcium signaling in dendrites of hippocampal pyramidal neurons. Anпu Rev Physiol 60: 327-346.
Majewska AK, Newton JR, Sur M. 2006. Remodeling of synaptic structure in sensory cortical areas in vivo. J Neurosci 26: 3021-3029.

Maletic-Savatic M, Lenn NJ, Trimmer JS. 1995. Differential spatiotemporal expression of $\mathrm{K}^{+}$channel polypeptides in rat hippocampal neurons developing in situ and in vitro. J Neurosci 15: 3840-3851.

Maletic-Savatic M, Malinow R, Svoboda K. 1999. Rapid dendritic morphogenesis in CA1 hippocampal dendrites induced by synaptic activity. Science 283: 1923-1927.

Malinow R, Malenka RC. 2002. AMPA receptor trafficking and synaptic plasticity. Annu Rev Neurosci 25: 103-126.

Malinow R, Mainen ZF, Hayashi Y. 2000. LTP mechanisms: From silence to four-lane traffic. Curr Opin Neurobiol 10: 352-357.

Manahan-Vaughan D, Schwegler H. 2011. Strain-dependent variations in spatial learning and in hippocampal synaptic plasticity in the dentate gyrus of freely behaving rats. Front Behav Neurosci 5: 7.

Marinesco S, Carew TJ. 2002. Serotonin release evoked by tail nerve stimulation in the CNS of Aplysia: Characterization and relationship to heterosynaptic plasticity. $J$ Neurosci 22: 2299-2312.

Marrone DF. 2005. The morphology of bi-directional experience-dependent cortical plasticity: A meta-analysis. Brain Res Brain Res Rev 50: 100-113.

Martin KC. 2004. Local protein synthesis during axon guidance and synaptic plasticity. Curr Opin Neurobiol 14: 305-310.

Martin EC, Casadio A, Zhu H, Yaping E, Rose J, Chen M, Bailey CH, Kandel ER. 1997a. Synapse-specific long-term facilitation of Aplysia sensory somatic synapses: A function for local protein synthesis memory storage. Cell 91: 927-938.

Martin KC, Michael D, Rose JC, Barad M, Casadio A, Zhu H, Kandel ER. 1997b. MAP kinase translocates into the nucleus of the presynaptic cell and is required for longterm facilitation in Aplysia. Neuron 18: 899-912.

Matsuo N, Reijmers L, Mayford M. 2008. Spine-type-specific recruitment of newly synthesized AMPA receptors with learning. Science 319: 1104-1107.

Matsuzaki M, Ellis-Davies GC, Nemoto T, Miyashita Y, Iino M, Kasai H. 2001. Dendritic spine geometry is critical for AMPA receptor expression in hippocampal CA1 pyramidal neurons. Nat Neurosci 4: 1086-1092.

Matsuzaki M, Honkura N, Ellis-Davies GC, Kasai H. 2004. Structural basis of long-term potentiation in single dendritic spines. Nature 429: 761-766.

Mauelshagen J, Parker GR, Carew TJ. 1996. Dynamics of induction and expression of long-term synaptic facilitation in Aplysia. J Neurosci 16: 7099-7108.

Mayford M, Barzilai A, Keller F, Schacher S, Kandel ER. 1992. Modulation of an NCAM-related adhesion molecule with long-term synaptic plasticity in Aplysia. Science 256: $638-644$.

Mayford M, Siegelbaum SA, Kandel ER. 2012. Synapses and memory storage. Cold Spring Harb Perspect Biol 4: a005751.

McAllister AM. 2007. Dynamic aspects of CNS synapse formation. Ann Rev Neurosci 30: 425-450. 
C.H. Bailey et al.

Meinertzhagen IA, Takemura SY, Lu Z, Huang S, Gao S, Ting CY, Lee CH. 2009. From form to function: The ways to know a neuron. J Neurogenet 23: 68-77.

Mendez P, De Roo M, Poglia L, Klauser P, Muller D. 2010. $\mathrm{N}$-cadherin mediates plasticity-induced long-term spine stabilization. J Cell Biol 189: 589-600.

Minerbi A, Kahana R, Goldfeld L, Kaufman M, Marom S, Ziv NE. 2009. Long-term relationships between synaptic tenacity, synaptic remodeling, and network activity. PLoS Biol 7: e1000136.

Miniaci MC, Kim J-H, Puthenveettil S, Si K, Zhu H, Kandel ER, Bailey CH. 2008. Sustained CPEB-dependent local protein synthesis is required to stabilize synaptic growth for persistence of long-term facilitation in Aplysia. Neuron 59: 1024-1036.

Mishchenko Y, Hu T, Spacek J, Mendenhall J, Harris KM, Chklovskii DB. 2010. Ultrastructural analysis of hippocampal neuropil from the connectomics perspective. Neuron 67: 1009-1020.

Miyashita T, Kubo Y. 1997. Localization and developmental changes of the expression of two inward rectifying $\mathrm{K}^{+}$. channel proteins in the rat brain. Brain Res 750: 251-263.

Moczulska KE, Tinter-Thiede J, Peter M, Ushakova L, Wernle T, Bathellier B, Rumpel S. 2013. Dynamics of dendritic spines in the mouse auditory cortex during memory formation and memory recall. Proc Natl Acad Sci 110: 18315-18320.

Mohns EJ, Blumberg MS. 2008. Synchronous bursts of neuronal activity in the developing hippocampus: Modulation by active sleep and association with emerging gamma and $\theta$ rhythms. J Neurosci 28: 10134-10144.

Molnar E, Pickard L, Duckworth JK. 2002. Developmental changes in ionotropic glutamate receptors: Lessons from hippocampal synapses. Neuroscientist 8: 143-153.

Mondin M, Labrousse V, Hosy E, Heine M, Tessier B, Levet F Poujol C, Blanchet C, Choquet D, Thoumine O. 2011. Neurexin-neuroligin adhesions capture surface-diffusing AMPA receptors through PSD-95 scaffolds. J Neurosci 31: 13500-13515.

Montarolo PG, Goelet P, Castellucci VF, Morgan J, Kandel ER, Schacher S. 1986. A critical period for macromolecular synthesis in long-term heterosynaptic facilitation in Aplysia. Science 234: 1249-1254.

Morgan SL, Teyler TJ. 2001. Electrical stimuli patterned after the $\theta$-rhythm induce multiple forms of LTP. J Neurophysiol 86: 1289-1296.

Moser MB, Trommald M, Egeland T, Andersen P. 1997. Spatial training in a complex environment and isolation alter the spine distribution differently in rat CA1 pyramidal cells. J Comp Neurol 380: 373-381.

Moser EI, Krobert KA, Moser MB, Morris RG. 1998. Impaired spatial learning after saturation of long-term potentiation. Science 281: 2038-2042.

Murata Y, Constantine-Paton M. 2013. Postsynaptic density scaffold SAP102 regulates cortical synapse development through EphB and PAK signaling pathway. J Neurosci 33: 5040-5052.

Nagerl UV, Eberhorn N, Cambridge SB, Bonhoeffer T. 2004. Bidirectional activity-dependent morphological plasticity in hippocampal neurons. Neuron 44: 759-767.
Nagerl UV, Kostinger G, Anderson JC, Martin KA, Bonhoeffer T. 2007. Protracted synaptogenesis after activitydependent spinogenesis in hippocampal neurons. J Neurosci 27: 8149-8156.

Nair D, Hosy E, Petersen JD, Constals A, Giannone G, Choquet D, Sibarita JB. 2013. Super-resolution imaging reveals that AMPA receptors inside synapses are dynamically organized in nanodomains regulated by PSD95. $J$ Neurosci 33: 13204-13224.

Nelson SB, Turrigiano GG. 2008. Strength through diversity. Neuron 60: 477-482.

Nguyen PV, Kandel ER. 1997. Brief $\theta$-burst stimulation induces a transcription-dependent late phase of LTP requiring cAMP in area CA1 of the mouse hippocampus. Learn Mem 4: 230-243.

Nicholson DA, Trana R, Katz Y, Kath WL, Spruston N, Geinisman Y. 2006. Distance-dependent differences in synapse number and AMPA receptor expression in hippocampal CA1 pyramidal neurons. Neuron 50: 431-442.

Nolt MJ, Lin Y, Hruska M, Murphy J, Sheffler-Colins SI, Kayser MS, Passer J, Bennett MV, Zukin RS, Dalva MB. 2011. EphB controls NMDA receptor function and synaptic targeting in a subunit-specific manner. $J$ Neurosci 31: $5353-5364$.

Nuriya M, Huganir RL. 2006. Regulation of AMPA receptor trafficking by N-cadherin. J Neurochem 97: 652-661.

Ostroff LE, Fiala JC, Allwardt B, Harris KM. 2002. Polyribosomes redistribute from dendritic shafts into spines with enlarged synapses during LTP in developing rat hippocampal slices. Neuron 35: 535-545.

Ostroff LE, Cain CK, Bedont J, Monfils MH, Ledoux JE. 2010. Fear and safety learning differentially affect synapse size and dendritic translation in the lateral amygdala. Proc Natl Acad Sci 107: 9418-9423.

Ouyang Y, Wong M, Capani F, Rensing N, Lee CS, Liu Q, Neusch C, Martone ME, Wu JY, Yamada K, et al. 2005. Transient decrease in F-actin may be necessary for translocation of proteins into dendritic spines. Eur J Neurosci 22: 2995-3005.

Park M, Salgado JM, Ostroff L, Helton TD, Robinson CG, Harris KM, Ehlers MD. 2006. Plasticity-induced growth of dendritic spines by exocytic trafficking from recycling endosomes. Neuron 52: 817-830.

Park MK, Choi YM, Kang YK, Petersen OH. 2008. The endoplasmic reticulum as an integrator of multiple dendritic events. Neuroscientist 14: 68-77.

Peters A, Palay SL, Webster D. 1976. The fine structure of the nervous system: The neurons and supporting cells. W.B. Saunders, Philadelphia.

Petralia RS, Esteban JA, Wang YX, Partridge JG, Zhao HM, Wenthold RJ, Malinow R. 1999. Selective acquisition of AMPA receptors over postnatal development suggests a molecular basis for silent synapses. Nat Neurosci 2: 3136.

Phillips LL, Pollack AE, Steward O. 1990. Protein synthesis in the neuropil of the rat dentate gyrus during synapse development. J Neurosci Res 26: 474-482.

Pierce JP, van Leyen K, McCarthy JB. 2000. Translocation machinery for synthesis of integral membrane and secretory proteins in dendritic spines. Nat Neurosci 3: 311313. 
Poirazi P, Brannon T, Mel BW. 2003. Arithmetic of subthreshold synaptic summation in a model CAl pyramidal cell. Neuron 37: 977-987.

Popov VI, Davies HA, Rogachevsky VV, Patrushev IV, Errington ML, Gabbott PL, Bliss TV, Stewart MG. 2004 Remodelling of synaptic morphology but unchanged synaptic density during late phase long-term potentiation (LTP): A serial section electron micrograph study in the dentate gyrus in the anaesthetised rat. Neurosci 128: 251-262.

Puthanveettil SV, Monje FJ, Miniaci MC, Choi YB, Karl KA, Khandros E, Gawinowicz MA, Sheetz MP, Kandel ER. 2008. A new component in synaptic plasticity: Upregulation of kinesin in the neurons of the gill-withdrawal reflex. Cell 135: 960-973.

Rajasethupathy P, Fiumara F, Sheridan R, Betel D, Puthanveettil SV, James J, Russo JJ, Sander C, Tuschl T, Kandel ER. 2009. Characterization of small RNAs in Aplysia reveals a role for MIR-124 in constraining long-term synaptic plasticity through CREB. Neuron 66: 803-817.

Rajasethupathy P, Antonov I, Sheridan R, Frey S, Sander C, Tuschl T, Kandel ER. 2012. A role for neuronal piRNAs in the epigenetic control of memory-related synaptic plasticity. Cell 149: 693-707.

Ramón y Cajal S. 1894. Croonian lecture. La fine structure des centres nerveux. Proc $R$ Soc London 55: 444-468; translated in De Felipe J and Jones EG. 1988. Cajal on the cerebral cortex. An annotated translation of the complete writings, pp. 83-88. Oxford University Press, New York.

Raymond CR, Redman SJ. 2006. Spatial segregation of neuronal calcium signals encodes different forms of LTP in rat hippocampus. J Physiol 570: 97-111.

Restivo L, Vetere G, Bontempi B, Ammassari-Teule M. 2009. The formation of recent and remote memory is associated with time-dependent formation of dendritic spines in the hippocampus and anterior cingulate cortex. J Neurosci 29: 8206-8214.

Reymann KG, Frey JU. 2007. The late maintenance of hippocampal LTP: Requirements, phases, "synaptic tagging," "late-associativity" and implications. Neuropharmacology 52: $24-40$.

Rogerson T, Cai DJ, Frank A, Sano Y, Shobe J, Lopez-Aranda MF, Silva AJ. 2014. Synaptic tagging during memory allocation. Nat Rev Neurosci 15: 157-169.

Rongo C, Kaplan JM. 1999. CaMKII regulates the density of central glutamatergic synapses in vivo. Nature 402: 195199.

Sabo SL, Gomes RA, McAllister AK. 2006. Formation of presynaptic terminals at predefined sites along axons. $J$ Neurosci 26: 10813-10825.

Saglietti L, Dequidt C, Kamieniarz K, Rousset MC, Valnegri P, Thoumine O, Beretta F, Fagni L, Choquet D, Sala C, et al. 2007. Extracellular interactions between GluR2 and Ncadherin in spine regulation. Neuron 54: 461-477.

Sanders J, Cowansage K, Baumgärtel K, Mayford M. 2012. Elimination of dendritic spines with long-term memory is specific to active circuits. J Neurosci 32: 12570-12578.

Sans N, Petralia RS, Wang YX, Blahos J, Hell JW, Wenthold RJ. 2000. A developmental change in NMDA receptorassociated proteins at hippocampal synapses. J Neurosci 20: $1260-1271$.
Schacher S, Hu JY. 2014. The less things change, the more they are different: Contributions of long-term synaptic plasticity and homeostasis to memory. Learn Mem 21: $128-134$.

Scheiffele P. 2003. Cell-cell signaling during synapse formation in the CNS. Annu Rev Neurosci 26: 485-508.

Scheiffele P, Fan J, Choih J, Fetter R, Serafini T. 2000. Neuroligin expressed in nonneuronal cells triggers presynaptic development in contacting axons. Cell 101: 657-669.

Schwartz H, Castellucci VF, Kandel ER. 1971. Functions of identified neurons and synapses in abdominal ganglion of Aplysia in absence of protein synthesis. J Neurophysiol 34: 9639-9653.

Sebeo J, Hsiao K, Bozdagi O, Dumitriu D, Ge Y, Zhou Q, Benson DL. 2009. Requirement for protein synthesis at developing synapses. J Neurosci 29: 9778-9793.

Senkov O, Sun M, Weinhold B, Gerardy-Schahn R, Schachner M, Dityatev A. 2006. Polysialylated neural cell adhesion molecule is involved in induction of long-term potentiation and memory acquisition and consolidation in a fear-conditioning paradigm. J Neurosci 26: 10888109898.

Sfakianos MK, Eisman A, Gourley SL, Bradley WD, Scheetz AJ, Settleman J, Taylor JR, Greer CA, Williamson A, Koleske AJ. 2007. Inhibition of Rho via Arg and p190RhoGAP in the postnatal mouse hippocampus regulates dendritic spine maturation, synapse and dendrite stability, and behavior. J Neurosci 27: 10982-10992.

Shapira M, Zhai RG, Dresbach T, Bresler T, Torres VI, Gundelfinger ED, Ziv NE, Garner CC. 2003. Unitary assembly of presynaptic active zones from Piccolo-Bassoon transport vesicles. Neuron 38: 237-252.

Sheng M, Hoogenraad CC. 2007. The postsynaptic architecture of excitatory synapses: A more quantitative view. Annu Rev Biochem 76: 823-847.

Shepherd GM, Harris KM. 1998. Three-dimensional structure and composition of $\mathrm{CA} 3 \rightarrow \mathrm{CA} 1$ axons in rat hippocampal slices: Implications for presynaptic connectivity and compartmentalization. J Neurosci 18: 8300-8310.

Sherrington CS. 1897. The central nervous system. In $A$ textbook of physiology, 7th ed. (ed. Foster M), Vol. 3. MacMillan, London.

Shu X, Lev-Ram V, Deerinck TJ, Qi Y, Ramko EB, Davidson MW, Jin Y, Ellisman MH, Tsien RY. 2011. A genetically encoded tag for correlated light and electron microscopy of intact cells, tissues, and organisms. PLoS Biol 9: e1001041.

* Si K. 2015. Long-term maintenance. Cold Spring Harb Perspect Biol doi: 10.1101/cshperspect.a021774.

Si K, Giustetto M, Etkin A, Hsu R, Janisiewicz AM, Miniaci MC, Kim JH, Zhu H, Kandel ER. 2003. A neuronal isoform of CPEB regulates local protein synthesis and stabilizes synapse-specific long-term facilitation in Aplysia. Cell 115: 893-904.

Soler-Llavina GJ, Arstikaitis P, Morishita W, Ahmad M, Sudhof TC, Malenka RC. 2013. Leucine-rich repeat transmembrane proteins are essential for maintenance of long-term potentiation. Neuron 79: 439-446.

Song JY, Ichtchenko K, Sudhof TC, Brose N. 1999. Neuroligin 1 is a postsynaptic cell-adhesion molecule of excitatory synapses. Proc Natl Acad Sci 96: 1100-1105. 
C.H. Bailey et al.

Sorra KE, Harris KM. 2000. Overview on the structure, composition, function, development, and plasticity of hippocampal dendritic spines. Hippocampus 10: 501511.

Sorra KE, Mishra A, Kirov SA, Harris KM. 2006. Dense core vesicles resemble active-zone transport vesicles and are diminished following synaptogenesis in mature hippocampal slices. Neurosci 141: 2097-2106.

Spacek J, Harris KM. 1997. Three-dimensional organization of smooth endoplasmic reticulum in hippocampal CA1 dendrites and dendritic spines of the immature and mature rat. J Neurosci 17: 190-203.

Spacek J, Harris KM. 1998. Three-dimensional organization of cell adhesion junctions at synapses and dendritic spines in area CAl of the rat hippocampus. J Comp Neurol 393: 58-68.

Spacek J, Lieberman AR. 1974. Ultrastructure and threedimensional organization of synaptic glomeruli in rat somatosensory thalamus. J Anat 117: 487-516.

Stan A, Pielarski KN, Brigadski T, Wittenmayer N, Fedorchenko O, Gohla A, Lessmann V, Dresbach T, Gottmann K. 2010. Essential cooperation of N-cadherin and neuroligin-1 in the transsynaptic control of vesicle accumulation. Proc Natl Acad Sci 107: 11116-11121.

Staubli U, Lynch G. 1987. Stable hippocampal long-term potentiation elicited by " $\theta$ " pattern stimulation. Brain Res 435: 227-234.

Steiner P, Higley MJ, Xu W, Czervionke BL, Malenka RC, Sabatini BL. 2008. Destabilization of the postsynaptic density by PSD-95 serine 73 phosphorylation inhibits spine growth and synaptic plasticity. Neuron 60: 788 802.

Stettler DD, Yamahachi H, Li W, Denk W, Gilbert CD. 2006 Axons and synaptic boutons are highly dynamic in adult visual cortex. Neuron 49: 877-887.

Steward O, Schuman EM. 2001. Protein synthesis at synaptic sites on dendrites. Annu Rev Neurosci 24: 299-325.

Stewart MG, Medvedev NI, Popov VI, Schoepfer R, Davies HA, Murphy K, Dallerac GM, Kraev IV, Rodriguez JJ. 2005. Chemically induced long-term potentiation increases the number of perforated and complex postsynaptic densities but does not alter dendritic spine volume in CA1 of adult mouse hippocampal slices. Eur J Neurosci 21: $3368-3378$.

Stuart G, Spruston N, Hausser M. 2008. Dendrites, 2nd ed. Oxford University Press, New York.

Sudhof TC. 2008. Neuroligins and neurexins link synaptic function to cognitive disease. Nature 455: 903-911.

Sutton MA, Masters SE, Bagnall MW, Carew TJ. 2001. Molecular mechanisms underlying a unique intermediate phase of memory in Aplysia. Neuron 31: 143-154.

Sytnyk V, Leshchyns'ka I, Delling M, Dityateva G, Dityatev A, Schachner M. 2002. Neural cell adhesion molecule promotes accumulation of TGN organelles at sites of neuron-to-neuron contacts. J Cell Biol 159: 649-661.

Takeuchi T, Duszkiewicz AJ, Morris RG. 2014. The synaptic plasticity and memory hypothesis: Encoding, storage and persistence. Philos Trans R Soc Lond B Biol Sci 369: 20130288.

Tanaka H, Shan W, Phillips GR, Arndt K, Bozdagi O, Shapiro L, Huntley GW, Benson DL, Colman DR. 2000. Mo- lecular modification of $\mathrm{N}$-cadherin in response to synaptic activity. Neuron 25: 93-107.

Toni N, Teng EM, Bushong EA, Aimone JB, Zhao C, Consiglio A, van Praag H, Martone ME, Ellisman MH, Gage FH. 2007. Synapse formation on neurons born in the adult hippocampus. Nat Neurosci 10: 727-734.

Trommald M, Hulleberg G, Andersen P. 1996. Long-term potentiation is associated with new excitatory spine synapses on rat dentate granule cells. Learn Mem 3: 218-228.

Turrigiano G. 2007. Homeostatic signaling: The positive side of negative feedback. Curr Opin Neurobiol 17: 318 324.

Turrigiano GG, Nelson SB. 2004. Homeostatic plasticity in the developing nervous system. Nat Rev Neurosci 5: $97-$ 107.

Uchida N, Honjo Y, Johnson KR, Wheelock MJ, Takeichi M. 1996. The catenin/cadherin adhesion system is localized in synaptic junctions bordering transmitter release zones. J Cell Biol 135: 767-779.

Udo H, Jin I, Kim J-H, Li H-L, Youn T, Hawkins RD, Kandel ER, Bailey CH. 2005. Serotonin-induced regulation of the actin network for learning-related synaptic growth requires CdC42, N-WASP and PAK in Aplysia sensory neurons. Neuron 45: 887-901.

Van Harreveld A, Fifkova E. 1975. Swelling of dendritic spines in the fascia dentata after stimulation of the perforant fibers as a mechanism of post-tetanic potentiation. Exp Neurol 49: 736-749.

Van Horn SC, Erisir A, Sherman SM. 2000. Relative distribution of synapses in the A-laminae of the lateral geniculate nucleus of the cat. J Comp Neurol 416: 509-520.

Vaughn JE. 1989. Fine structure of synaptogenesis in the vertebrate central nervous system. Synapse 3: 255-285.

Ventura R, Harris KM. 1999. Three-dimensional relationships between hippocampal synapses and astrocytes. $J$ Neurosci 19: 6897-6906.

Wainwright ML, Zhang H, Byrne JH, Cleary LJ. 2002. Localized neuronal outgrowth induced by long-term sensitization training in Aplysia. J Neurosci 22: 4132-4141.

Waites CL, Craig AM, Garner CC. 2005. Mechanisms of vertebrate synaptogenesis. Annu Rev Neurosci 28: 251274.

Wang Y, Zhu G, Briz V, Hsu YT, Bi X, Baudry M. 2014. A molecular brake controls the magnitude of long-term potentiation. Nat Commun 5: 3051.

Wilke SA, Antonios JK, Bushong EA, Badkoobehi A, Malek E, Hwang M, Terada M, Ellisman MH, Ghosh A. 2013. Deconstructing complexity: Serial block-face electron microscopic analysis of the hippocampal mossy fiber synapse. J Neurosci 33: 507-522.

Witcher MR, Kirov SA, Harris KM. 2007. Plasticity of perisynaptic astroglia during synaptogenesis in the mature rat hippocampus. Glia 55: 13-23.

Wittenmayer N, Korber C, Liu H, Kremer T, Varoqueaux F, Chapman ER, Brose N, Kuner T, Dresbach T. 2009. Postsynaptic Neuroligin1 regulates presynaptic maturation. Proc Natl Acad Sci 106: 13564-13569.

Xu T, Yu X, Perlik AJ, Tobin WF, Zweig JA, Tennant K, Jones T, Zuo Y. 2009. Rapid formation and selective stabilization of synapses for enduring motor memories. Nature 462: $915-919$. 
Yang Y, Wang XB, Frerking M, Zhou Q. 2008. Spine expansion and stabilization associated with long-term potentiation. J Neurosci 28: 5740-5751.

Yang G, Pan F, Gan WB. 2009. Stably maintained dendritic spines are associated with lifelong memories. Nature 462: 920-924.

Young JZ, Nguyen PV. 2005. Homosynaptic and heterosynaptic inhibition of synaptic tagging and capture of long-term potentiation by previous synaptic activity. $J$ Neurosci 25: 7221-7231.

Yuste R, Bonhoeffer T. 2001. Morphological changes in dendritic spines associated with long-term synaptic plasticity. Annu Rev Neurosci 24: 1071-1089.
Zhai RG, Vardinon-Friedman H, Cases-Langhoff C, Becker B, Gundelfinger ED, Ziv NE, Garner CC. 2001. Assembling the presynaptic active zone: A characterization of an active one precursor vesicle. Neuron 29: 131-143.

Zhou Q, Homma KJ, Poo MM. 2004. Shrinkage of dendritic spines associated with long-term depression of hippocampal synapses. Neuron 44: 749-757.

Zito K, Parnas D, Fetter RD, Isacoff EY, Goodman CS. 1999. Watching a synapse grow: Noninvasive confocal imaging of synaptic growth in Drosophila. Neuron 22: 719-729.

Ziv NE, Garner CC. 2004. Cellular mechanisms of presynaptic assembly. Nat Rev Neurosci 5: 385-399. 


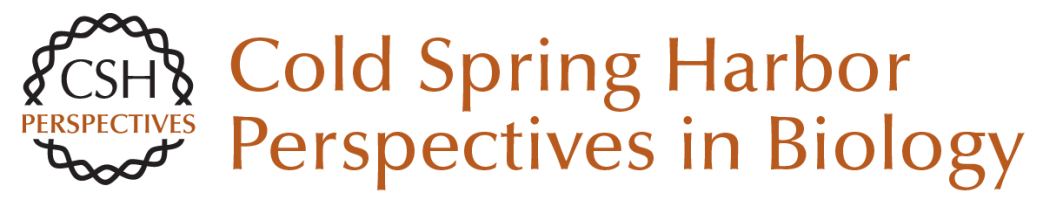

\section{Structural Components of Synaptic Plasticity and Memory Consolidation}

Craig H. Bailey, Eric R. Kandel and Kristen M. Harris

Cold Spring Harb Perspect Biol 2015; doi: 10.1101/cshperspect.a021758

\section{Subject Collection Learning and Memory}

Large-Scale Fluorescence Calcium-Imaging

Methods for Studies of Long-Term Memory in

Behaving Mammals

Pablo Jercog, Thomas Rogerson and Mark J. Schnitzer

Exploring Memory Representations with

Activity-Based Genetics

Mark Mayford and Leon Reijmers

The Origins and Organization of Vertebrate

Pavlovian Conditioning

Michael S. Fanselow and Kate M. Wassum

The Corticohippocampal Circuit, Synaptic

Plasticity, and Memory

Jayeeta Basu and Steven A. Siegelbaum

Motor Learning and the Cerebellum

Chris I. De Zeeuw and Michiel M. Ten Brinke

The Striatum: Where Skills and Habits Meet Ann M. Graybiel and Scott T. Grafton

Molecular Genetic Strategies in the Study of

\section{Corticohippocampal Circuits}

Christopher C. Angelakos and Ted Abel

Nonassociative Learning in Invertebrates John H. Byrne and Robert D. Hawkins
The Role of Functional Prion-Like Proteins in the

Persistence of Memory

Kausik Si and Eric R. Kandel

Working Memory: Maintenance, Updating, and the

Realization of Intentions

Lars Nyberg and Johan Eriksson

Memory Retrieval in Mice and Men

Aya Ben-Yakov, Yadin Dudai and Mark R. Mayford

Reconsolidation and the Dynamic Nature of Memory

Karim Nader

Memory Consolidation

Larry R. Squire, Lisa Genzel, John T. Wixted, et al.

Structural Components of Synaptic Plasticity and

Memory Consolidation

Craig H. Bailey, Eric R. Kandel and Kristen M. Harris

Associative Learning in Invertebrates

Robert D. Hawkins and John H. Byrne

The Regulation of Transcription in Memory

Consolidation

Cristina M. Alberini and Eric R. Kandel

For additional articles in this collection, see http://cshperspectives.cshlp.org/cgi/collection/

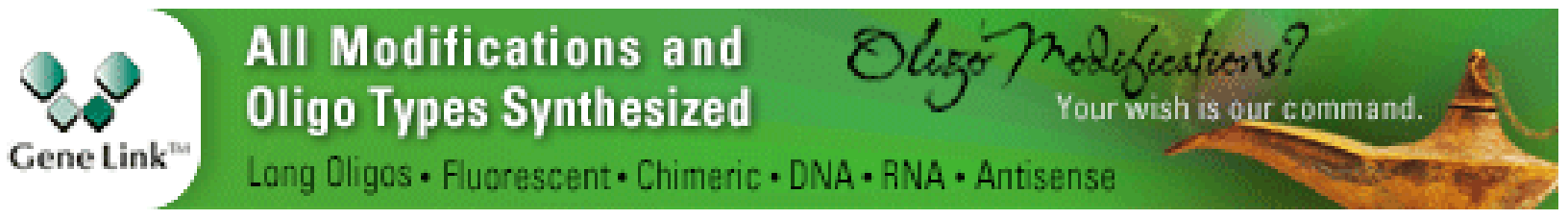

